Illinois State University

ISU ReD: Research and eData

Theses and Dissertations

$6-5-2015$

\title{
Rural High School Special Education Teachers' Perceptions Related to Structured Work Experiences
}

Abigail Meghan Christina Lies

Illinois State University, amlies@ilstu.edu

Follow this and additional works at: https://ir.library.illinoisstate.edu/etd

Part of the Special Education Administration Commons, and the Special Education and Teaching Commons

\section{Recommended Citation}

Lies, Abigail Meghan Christina, "Rural High School Special Education Teachers' Perceptions Related to Structured Work Experiences" (2015). Theses and Dissertations. 436.

https://ir.library.illinoisstate.edu/etd/436

This Thesis is brought to you for free and open access by ISU ReD: Research and eData. It has been accepted for inclusion in Theses and Dissertations by an authorized administrator of ISU ReD: Research and eData. For more information, please contact ISUReD@ilstu.edu. 


\title{
RURAL HIGH SCHOOL SPECIAL EDUCATION TEACHERS' PERCEPTIONS RELATED TO STRUCTURED WORK EXPERIENCES
}

\begin{abstract}
Abigail Lies
97 Pages

August 2015

This exploratory study examined the perspectives of rural secondary special education teachers and related service professionals on structured work experiences for youth with disabilities. An online survey was developed for this study and distributed to teachers and related service professionals through school principals. Rural schools were identified using the National Center for Educational Statistics. The survey included sections on respondent and school demographics, perceptions on the value of, frequency of participation in, and quality of implementation of structured work experiences. Additional sections included perceptions on the level of influence specific barriers have on the implementation of structured work experiences. A total of 51 individuals responded to the survey, and 39 usable surveys are included in the analysis.

Data were analyzed with descriptive statistics. Frequencies, percentages, and standard deviations were calculated. Findings suggest that respondents perceive structured work experiences as beneficial to the development of students with disabilities but that those students do not frequently participate in the activities. Several specific findings are suggested for further consideration. First, there is a disconnect between those
\end{abstract}


activities seen as most beneficial to students and those activities students participate in most frequently. Second, transportation is a continued and significant barrier for rural school programs. Third, respondents did not view administrator support as a significant barrier but did identify multiple barriers that could be influenced by administrative leadership. Fourth, findings suggest a limited understanding of the longitudinal nature of career development and the recommended sequence of structured work experiences.

Though this is an exploratory study with a small sample, the findings point to several important areas for further consideration. Future research needs are presented. 
RURAL HIGH SCHOOL SPECIAL EDUCATION TEACHERS'

\section{PERCEPTIONS RELATED TO STRUCTURED}

WORK EXPERIENCES

ABIGAIL LIES

A Thesis Submitted in Partial Fulfillment of the Requirements for the Degree of MASTER OF SCIENCE

Department of Special Education

ILLINOIS STATE UNIVERSITY

2015 
Copyright 2015 Abigail Lies 
RURAL HIGH SCHOOL SPECIAL EDUCATION TEACHERS'

\title{
PERCEPTIONS RELATED TO STRUCTURED
}

WORK EXPERIENCES

\author{
ABIGAIL LIES
}

COMMITTEE MEMBERS:

Debra L. Shelden, Chair

Sharon Doubet

Nicole M. Uphold 


\section{ACKNOWLEDGMENTS}

I would like to thank my committee members, family, and friends for their support and encouragement throughout this project. I would first like to thank Debra Shelden my mentor and committee chair for her support throughout this project. I could not have completed this project without your guidance, feedback, and knowledge. We spent a number of hours working together on this project. Second I would like to thank the members of my committee Sharon Doubet and Nicole Uphold. Their support and feedback are appreciated. I would like to thank all members of my committee for their time and dedication to helping and guiding me through this project.

I would like to thank my parents and friends for their support and encouragement while I was involved with this project. I would have not been able to finish without them. I am grateful to each and every individual who supported me throughout this project. I could not have done it without each of you. Thank you.

A. L. 


\section{CONTENTS}

Page

ACKNOWLEDGMENTS

CONTENTS

TABLES $\quad$ V

CHAPTER

I. INTRODUCTION AND STATEMENT OF PROBLEM 1

Search Procedures 1

Employment Outcomes for Young Adults with Disabilities 2

Benefits of Structured Work Experiences 3

Availability of Structured Work Experience for Students with

Disabilities 4

Factors that Affect Availability of Structured Work Experiences 5

Education Reform $\quad 5$

Labor Market $\quad 5$

Statement of Problem and Research Questions 6

$\begin{array}{ll}\text { Definition of Terms } & 8\end{array}$

II. REVIEW OF LITERATURE 9

Overview of Transition $\quad 9$

The Importance of Structured Work Experiences 11

Types of Structured Work Experiences 13

Apprenticeship or Internship for Specific Career 16

Job Shadowing or Job Sampling $\quad 17$

Paid Job Outside of School Program 17

Paid or Unpaid Job as Part of School Program 18

School-Sponsored Enterprise or Youth-Run Business 18

Service Learning or Volunteer Activities $\quad 19$

Summer Jobs 19 
Other Experiences: Career Days and Fairs, Speakers from Local Businesses, and Tours of Local Businesses

Structured Work Experience Programs

Benefits of Structured Work Experiences

Determination of Employment Preferences and Interests

Dropout Prevention

Preparation for Post-School Employment

Barriers to Effective Implementation of Structured Work Experiences

Attitudes

Lack of Support from School Districts

Changes in Recent Legislation

Limited Community Access

Student and Parent Participation

Recommended Structured Work Experience Practices

Opportunity to Investigate a Variety of Career Options

Integration of Rigorous Instruction and Structured Work

Experience

Incorporation of Structured Work Experience into IEPs

Community Experiences

Parent Engagement

Current Structured Work Experience Practices

Implementation of Structured Work Experiences

Availability of Structured Work Experiences for Students With and Without Disabilities

Recommendations for Improving Access and Impact of Structured Work Experiences

School Districts

School Curriculum

Other

Structured Work Experiences in Rural Areas 
$\begin{array}{ll}\text { III. METHOD } & 40\end{array}$

Survey Instrument $\quad 40$

Participants $\quad 42$

Procedures 44

Data Analysis $\quad 44$

Participants Demographics $\quad 45$

School Characteristics $\quad 47$

IV. RESULTS 48

Research Question 1: Importance, Frequency of Participation, and Quality of Implementation of Structured Work Experiences 48

Importance of Structured Work Experiences 48

Benefit to student development 49

Influence on post-school outcomes 49

Appropriate grade level for participation $\quad 51$

Frequency of Participation by Students with Disabilities $\quad 52$

Comparison Between Importance and Frequency Ratings 54

Quality of Implementation $\quad 56$

Research Question 2: Barriers to Structured Work Experiences 56

$\begin{array}{lll}\text { V. DISCUSSION } & 60\end{array}$

$\begin{array}{ll}\text { Limitations } & 60\end{array}$

Discussion of Findings $\quad 61$

Research Question 1: Importance, Frequency of Participation, and Quality of Implementation of Structured Work Experiences 62

Research Question 2: Barriers to Structured Work Experiences 64

Benefits to Students 65

Lack of Transportation $\quad 66$

Significance of Administrator Support $\quad 67$

Limited Connection to Middle School Experiences 68

Influence of Structured Work Experiences on Post-School
Education

Implications for Research and Practice 69

$\begin{array}{ll}\text { REFERENCES } & 72\end{array}$

APPENDIX A: Survey Instrument 


\section{TABLES}

Table $\quad$ Page

1. Types of Structured Work Experiences 15

2. Demographics of Participants 46

3. School Characteristics 47

4. Ratings of the Importance of Specific Structured Work Experiences $\quad 50$

5. Ratings of the Influence Structured Work Experiences have on Specific Post-School Outcomes 51

6. Ratings of the Grade Level Appropriateness of Specific Structured Work Experiences

7. Ratings of the Frequency of Participation of Students with Disabilities in Specific Structured Work Experiences

8. Comparison of Mean Ratings of and Correlation Between Importance and Frequency of Specific Structured Work Experiences

9. Ratings of the Quality of Implementation of Specific Structured Work Experiences

10. Ratings of the Significance of Each Barrier to the Implementation of Structured Work Experiences 


\section{CHAPTER I}

\section{INTRODUCTION AND STATEMENT OF PROBLEM}

Structured work experiences are a significant component of transition plans for high school students with disabilities. These experiences facilitate transition to both employment and education settings. Structured work experiences foster student development of skills necessary to find and maintain employment after graduating from high school. In 1996, Kohler included structured work experiences as a component of the Taxonomy for Transition Programming. Kohler included apprenticeships, paid work experiences, work study programs, and job placement services as activities related to structured work experiences. Since then many aspects of structured work experiences have been identified as evidence based predictors to improve transition outcomes for students with disabilities.

\section{Search Procedures}

My research topic is structured work experiences for students with disabilities in rural schools. My search procedures included searches on ERIC, PsychINFO, and IOS Press. I searched for peer-reviewed articles from 1993 to the present, using the key search terms of structured work experiences, work-based learning, career development, job development, disabilities, secondary, employment, employment outcomes, rural, evidence-based practices, and transition. I also identified information on the website of

the Research and Training Center on Disabilities in Rural Communities supported by the 
University of Montana, as well as the National Center on Secondary Education and Transition and the National Secondary Transition and Technical Assistance website. The search resulted in locating articles, chapters, and other resources related to structured work experiences for students with and without disabilities.

\section{Employment Outcomes for Young Adults with Disabilities}

In $2013,17.6 \%$ of individuals with a disability in the United States were employed (United States Bureau of Labor Statistics, 2014), compared to $64 \%$ of individuals without a disability. For individuals with a disability who are of working age (age 16-64 years), only 26.8\% were employed. The unemployment rate for individuals with a disability was $13.2 \%$ compared to $7.1 \%$ for individuals with no disability. Additionally $34 \%$ of workers with a disability were only employed part time, compared to $19 \%$ of workers with no disability (United States Bureau of Labor Statistics, 2014).

Statistics for employment rates of young adults with a disability are better, though there remains a gap between young adults with and without disabilities. The National Longitudinal Transition Study 2 (NLTS2) reported "60\% of young adults with disabilities who had been out of high school for up to 8 years were employed for pay outside the home, compared with 66 percent of similarly aged young adults (21 to 25 years old) in

the general population, not a significant difference" (Newman et al., 2011, p. 53). Ninetyone percent of individuals with disabilities reported employment at some point since high school (Newman et al., 2011). Employment rates varied significantly across disability categories; $67 \%$ of individuals with learning disabilities were employed compared to $30 \%$ of individuals with deaf-blindness (Newman et al., 2011). The NLTS2 also indicated that $67 \%$ of individuals with disabilities worked full time, they earned an 
average of $\$ 10.40$ per hour, and 61\% received at least one benefit (Newman et al., 2011).

Post high school education data provided by the NLTS2 indicates that individuals in the general population were more likely to attend a four-year college or university, and individuals with disabilities were more likely to attend a two-year college or postsecondary vocational school (Newman et al., 2011). Sixty-seven percent of young adults in the general population were enrolled in any post-secondary school compared to $60 \%$ of young adults with disabilities (Newman et al., 2011). Completion rates for individuals with disabilities were higher for those who attended a two-year college or post-secondary vocational school than a four-year college or university (Newman et al., 2011).

\section{Benefits of Structured Work Experiences}

Structured work experiences benefit youth in many ways, including (a) providing opportunities to learn employment skills and determine employment preferences and interests (Lindstrom, Doren, \& Miesch, 2011; Lindstrom, Paskey, et al., 2007; Stasz \& Stern, 1998), (b) increasing the likelihood of completing high school (Martin, Tobin, \& Sugai, 2002), and (c) preparing for employment and education after high school (Kim \& Dymond, 2010; Lindstrom, et al., 2011; White \& Weiner, 2004). A review of literature by Test, Mazzotti, et al. (2009) identified paid work experiences, career awareness, vocational education, community experiences, program of study, and work study to be predictors of post-school employment. Landmark, Ju, and Zhang (2010) reviewed literature of best transition practice and found that paid or unpaid work experience and employment preparation have been linked to positive post-school outcomes for students with disabilities. The strength of structured work experiences as a predictor for positive post-school outcomes necessitates a clear understanding of the extent to which students 
with disabilities are able to access these experiences as part of their transition services.

\section{Availability of Structured Work Experience for Students with Disabilities}

Limited research has been conducted on the availability of structured work experiences for youth with disabilities. Zhang, Ivester, Chen, and Katsiyannis (2005) surveyed 105 middle and high school special education lead teachers and 37 transition professionals regarding their perspectives on how transition best practices were provided in school districts and what services and experiences students received. They reported that $83.8 \%$ of students in respondents' schools receive school based work experiences, $74.6 \%$ take vocational or occupational courses, $73.9 \%$ o receive career information, and $69.0 \%$ have an opportunity to job shadow. Teachers reported that fewer than half of students experience supported employment or internship opportunities (Zhang et al., 2005). More recently, research has suggested that participation in structured work experiences is limited for any students with disabilities and unevenly available (Carter, Trainor, Cakiroglu, Swedeen, \& Owens, 2010). Carter et al., (2010) call for increased availability of structured work experiences for youth with disabilities. While research supports the importance of structured work experiences (Benz, Lindstrom, \& Yovanoff, 2000; Joshi, Bouck, \& Maeda, 2012; Lindstrom, et al., 2011; Nietupski et al., 2006; Rabren, Dunn, \& Chambers, 2002; Simonsen \& Neubert, 2012), implementation is lacking. Li, Bassett, and Hutchinson (2009) investigated perspectives of transition coordinators or specialists, special education teachers, and those with both roles and found a lack of preparation related to providing structured work experiences.

Carter, et al. (2010) surveyed administrators and school-level representatives about the availability of structured work experience, including career development and 
vocational activities, for transition age students with and without disabilities and the extent to which these activities were available to students with severe disabilities or emotional and behavioral disorders. Kim and Dymond (2010) surveyed special education teachers about their perceptions regarding benefits and barriers to the implementation of structured work experiences specifically community-based vocational instruction (CBVI), effective components of CBVI, and importance and use of components of CBVI. Collet-Klingenberg and Kolb (2011) surveyed special educators about their perceptions on transition programing components. The authors found three major barriers to these programs: (a) limited transportation, (b) lack of funding available for these programs, and (c) limited options available for students in rural areas (Collet-Klingenberg \& Kolb, 2011).

\section{Factors that Affect Availability of Structured Work Experiences}

\section{Education Reform}

Education reform in the past decade has not focused on community career development or structured work experiences. After the sunset of the School to Work Opportunity Act (STWOA), emphasis shifted via No Child Left Behind (NCLB) away from career development curricula. A lack of district support (Kim \& Dymond, 2010; Wandry et al., 2008) and changes in education legislation (Li, et al., 2009; Kim \& Dymond, 2010) have both been cited as barriers to wider availability of structured work experiences.

\section{Labor Market}

Demands in the workplace are changing. Current high school programs do not prepare students for workplace demands (Lindstrom, Doren, Flannery, \& Benz, 2012). 
Changing demands include understanding data, communicating clearly, learning rapidly, using technology, and working well in teams (Lindstrom et al., 2012). Structured work experiences may be particularly beneficial in preparing students to participate in these new workplace demands.

Labor market conditions include unemployment rate, employment growth, and earning levels; each of these has an impact on individual and community well-being (USDA, Employment and Education, 2014). The U.S. economy is recovering from the 2007-2009 recession (USDA, Rural America at a Glance, 2014). Rural employment remains below its 2007 peak (USDA, Rural America at a Glance, 2014). Between 2010 and 2014 rural employment grew by only $1.1 \%$ and as of mid-2014 remains more than 3\% below pre-recession levels (USDA, Rural America at a Glance, 2014).

Unemployment rates in both urban and rural areas have fallen from 10\% in late 2009 to just over 6\% in mid-2014 (USDA, Rural America at a Glance, 2014). Schools in rural areas may face additional barriers to offering structured work experiences, including more limited employment options (Collet-Klingenberg \& Kolb, 2011; Joshi, et al., 2012; Kim \& Dymond, 2010).

\section{Statement of Problem and Research Questions}

Structured work experiences are beneficial for individuals with disabilities to obtain and maintain post-school employment (Baer et al., 2003; Benz, et al., 2000; Joshi, et al., 2012; Lindstrom, et al., 2011; Nietupski et al., 2006; Rabren, et al., 2002; Simonsen \& Neubert, 2012). Paid employment or work experiences, vocational experiences, community experiences, work study, employment preparation, vocational training, community-based instruction, community-referenced curriculum, career 
education curriculum, and employability skills training have all been identified as best practices related to post-school transition and improved employment outcomes for students with disabilities (Kohler, 1993; Landmark, et al., 2010; Test, Mazzotti, et al., 2009). The barriers rural school districts face when implementing structured work experiences differ from schools located in other areas. Research exists on professionals' perspectives related to transition but addresses transition practices in general rather than structured work experiences specifically, does not specifically address implementation in rural schools, or is not recent enough to reflect the potential effects of changing workplace demands and education reform trends. The availability of and perceptions of value related to structured work experiences has potentially been affected by changes in school priorities and funding related to vocational opportunities (Collet- Klingenberg \& Kolb, 2011; Kim \& Dymond, 2010; Trainor, Carter, Owens, \& Swedeen, 2008; Wandry et al., 2008).

Limited research on current availability and perceptions of structured work experiences is available. No research focusing specifically on availability and perceptions of structured work experiences in rural school districts has been reported. The purpose of this study is to examine the perceptions of high school special education teachers in rural school districts related to structured work experiences. Specifically, the following research questions will be addressed:

1. What are rural special education teachers' perceptions of the (a) benefit of, (b) frequency of participation in, and (c) quality of implementation of structured work experiences? 
2. What are rural special education teachers' perceptions of the significance of barriers to implementation of structured work experiences?

\section{Definition of Terms}

Structured work experience refers to any community based volunteer, assessment, exploration, or training work or opportunity that helps students develop work goals, build employability skills, connect to work, and increase career opportunities and options. 
CHAPTER II

\section{REVIEW OF LITERATURE}

The proposed study will be an examination of the perceptions of special education teachers in rural schools related to structured work experiences. This chapter provides an overview of literature related to structured work experiences. First, I present an overview of transition legislation and reform surrounding structured work experiences. Next, I review the literature related to (a) importance, (b) types, (c) benefits, and (d) barriers of structured work experiences. Finally, I review literature related to (a) recommended practices, (b) current practices, (c) recommendations for improving students structured work experiences, and (d) structured work experiences in rural areas.

\section{Overview of Transition}

One of the most significant transitions that we make is the transition from high school to the beginning of adult life (Test, Aspel, \& Everson, 2006). Education laws have placed an emphasis on the importance of transition planning for students with disabilities in high school. The Individuals with Disabilities Education Improvement Act (IDEA) 2004 defines transition services as "a coordinated set of activities for a child with a disability that: (a) is designed to be within a results-oriented process, that is focused on improving the academic and functional achievement of the child with a disability to facilitate the child's movement from school to post-school activities, including postsecondary education, vocational education, integrated employment (including 
supported employment); continuing and adult education, adult services, independent living, or community participation; (b) is based on the individual child's needs, taking into account the child's strengths, preferences, and interests; and (c) includes instruction, related services, community experiences, the development of employment and other postschool adult living objectives, and, if appropriate, acquisition of daily living skills and functional vocational evaluation" [34 CFR 300.43 (a)] [20 U.S.C. 1401(34)]. This mandate requires that transition planning include identifying appropriate employment post-school objectives for students when they enter adulthood. Post-school goals for students with disabilities should reflect achievable, realistic expectations for adult life (Test et al., 2006).

Transition planning plays a large role in the Individualized Education Plan (IEP) of all high school students with disabilities; the IEP for a transition aged student should be completely geared toward facilitating progress toward the identified post-school goals. The importance of transition planning was reflected in the 1990 amendment to the Individuals with Disabilities Education Act, when transition services were first defined in the federal special education legislation. The legal mandates regarding transition services continued to evolve with subsequent amendments to IDEA as well as with related legislation.

The 1997 amendments to IDEA included changes to strengthen the delivery of students' transition services (IDEA, 1997). Related services were added to the list of possible transition services and vocational education was included as an educational activity to prepare student for transition (IDEA, 1997). The 2004 amendments changed outcome-oriented to results-oriented and added requirements to address both academic 
and functional achievement (IDEA, 2004). Potential transition services still include vocational education (IDEA, 2004). Student's strengths, preferences, and interests should be taken into account when determining their transition needs. Measureable postsecondary goals for beyond high school are required as a part of a student's IEP (IDEA, 1997).

In 1994 the Schools to Work Opportunities Act (STWOA) was passed in reaction to the changing needs of the workplace (Perry \& Wallace, 2012). This act delineated school-based learning, work-based learning, and connecting activities as the three components for any school-to-work program (Perry \& Wallace, 2012). The goal was to strengthen linkages between school and work by providing all students the opportunity to participate in performance-based education and training programs (National Transition Network, 1994). The School to Work Opportunities Act expired in 2001.

\section{The Importance of Structured Work Experiences}

The National Longitudinal Transition Study 2 (NLTS2) found that individuals with disabilities out of high school for up to eight years had, on average, held four jobs since leaving high school (Newman et al., 2011). Fifty-four percent of individuals had held their current job for at least 12 months (Newman et al., 2011). These individuals held a variety of jobs: 13\% worked in serving-related occupations including food preparation; $12 \%$ worked in sales and related occupations; $9 \%$ worked in administrative support or office related occupations; and $8 \%$ worked in construction and extraction, personal care and service, and transportation and material moving occupational categories (Newman et al., 2011). Forty-three percent of individuals reported job satisfaction and liked their job very much (Newman et al., 2011). The majority of 
individuals (55\%) reported finding a their job on their own; other job search methods included help from a family member (18\%), help from friends or acquaintances (17\%), help from an employment agency (8\%), and help from a teacher or other school staff member (4\%) (Newman et al., 2011).

Effective and perceived important transition practices have been identified in the literature. Test, Mazzotti et al. (2009) completed a review of secondary transition research to identify predictors of students' post-school success in education, employment, and independent living. The authors identified 16 evidence-based predictors; all 16 activities predicted success in student employment post-school. The 16 evidence-base predictors are: (a) career awareness, (b) community experiences, (c) exit exam requirements/high school diploma status, (d) inclusion in general education, (e) interagency collaboration, (f) occupational courses, (g) paid work experiences, (h) parental involvement, (i) program of study, (j) self-advocacy/self-determination, (k) selfcare/independent living, (l) social skills, (m) student support, (n) transition program, (o) vocational education, and (p) work study (Test, Mazzotti et al., 2009). Rowe et al. (2014) worked with experts in the fields of secondary transition and career technical education to create an operational definition of each predictor. The authors found research to support an additional predictor of students' post-school success, parent expectations was added as a supported predictor (Rowe et al., 2014).

Structured work experiences have been found to have a positive impact on these employment outcomes (Benz et al., 2000; Lindstrom et al., 2011; Nietupski et al., 2006; Rabren, et al., 2002; Simonsen \& Neubert, 2012). Work experiences help students build a foundation for employment after high school (Lindstrom et al., 2011). Rabren, et al. 
(2002) found that students with a paying job when they exited high school were 3.8 times more likely than students without to be employed one year after completing high school. At-risk students who participated in cooperative education are more likely to develop post-secondary education plans than their peers who did not participate (Gemici \& Rojewski, 2010). Through work-based learning activities, students learn job expectations that could increase their economic success (Estrada-Hernandez, Wadsworth, Nietupski, Warth, \& Winslow, 2008). For students to be successful in transition they need support in vocational training, community participation, and independent living (Estrada-Hernandez et al., 2008).

\section{Types of Structured Work Experiences}

Schools have provided structured work experiences and other career development activities for decades. Over time, a variety of terms and classifications have been used to identify these experiences. "Structured work experience" is an umbrella term used by Lindstrom et al. (2012) and refers "to a variety of work-based activities that connect students to work, build employability skills, and increase career options and opportunities" (Lindstrom et al., 2012, p. 191). Through structured work experiences, students receive instruction in the community (Test et al. 2006). Structured work experiences offer students the opportunity to practice occupational skills, develop work ethic, develop consistency, and develop responsibility in a real world setting (Lindstrom et al., 2011). In order for structured work experiences to be meaningful to students with disabilities, school personnel need to determine placement of students based on their skill and learning goals (Lindstrom et al., 2011). Personnel should be available to provide instruction and support for students while working toward achievement of these goals 
(Lindstrom et al., 2011). Job and related skill instruction provided in the community is termed community-based vocational instruction (CBVI) (Kim \& Dymond, 2010).

Work-based learning (WBL) is a term that was commonly used as a component of the School to Work Opportunity Act of 1994 (United States Department of Education, 1994). WBL refers to learning that is happening in the workplace to enhance student learning (Dutton, 1995). Stasz and Brewer (1998) defined WBL as "learning that is planned to contribute to the intellectual and career development of high school" students (p. 31). The goal of WBL provides students with experience in the world of work and increases future employment opportunities (Stasz \& Brewer, 1998). Students receive hand-on work experience to learn work-related skills and attitudes they would not be able to acquire in a classroom (Stasz \& Brewer, 1998). Through WBL students have on the job opportunities to learn high-level technical skills (Stasz \& Brewer, 1998). These skills may include (a) mastering procedures, (b) gaining an understanding of fundamental principles, (c) logical judgment, and (d) computer skills (Stasz \& Stern, 1998). Students also have the opportunity though WBL to develop personal and social skills including (a) initiative, (b) honesty, (c) commitment to improvement, and (d) career planning (Stasz \& Stern, 1998).

A variety of activities fall within the category of structured work experience. Specific structured work experience activities vary based on (a) the nature of student involvement in the work activity, (b) level of independence expected of student, (c) paid versus unpaid nature, and (d) on campus versus off campus. Existing literature describes ten general structured work experience activities. Those activities are summarized in Table 1. 
Table 1

Types of Structured Work Experiences

\begin{tabular}{ll}
\hline \multicolumn{1}{c}{ Models } & \multicolumn{1}{c}{ Definition } \\
\hline Apprenticeship or & Students work for an employer, paid or unpaid, to learn \\
internship for specific & about and industry or occupation. (Lindstrom et al., 2012; \\
career & School to work glossary of terms, National School to \\
& Work Office, 1999). Students learn an occupation while \\
& under the supervision of an experienced worker (Test et \\
& al., 2006). Youth apprenticeship combine school and \\
& work-based learning to teach students a specific \\
& occupation or cluster. Youth apprenticeships lead to post- \\
& secondary programs, entry-level jobs, or registered \\
& apprenticeship programs (National School to Work \\
& Office, 1999).
\end{tabular}

Career days or career fairs

Students learn about their career interest and abilities by meeting with post-secondary educators, employers, employees, or human resource professional (National School to Work Office, 1999).

Job shadowing or job sampling

Students explore a range of career objectives by spending a few hours observing at worksites alongside employees to develop an understanding of the job duties (National School to Work Office, 1999; Stasz \& Stern, 1998; Test et al., 2006).

Paid job outside of school program

Students engage in off-campus standard paid job, often after school or on weekends. (Lindstrom et al., 2012; Stasz \& Stern, 1998).

Paid or unpaid job as part of school program

Students engage in paid or unpaid work experiences in while supervised by school personnel. The students learn general work place skills (Lindstrom, 2014). These employment opportunities can provide students with a number of workplace experiences (Lindstrom, 2014).

School-sponsored enterprise or Youth-run Students manage and work with other classes or school activities to produce goods or provide services for others within the school setting (Lindstrom et al., 2012; National School to Work Office, 1999; Stasz \& Stern, 1998). Students create, produce, and sell various products they have created (Larson, 2011).

Table continues 
Service learning or volunteer activities

Speakers from local businesses

Summer jobs
Students usually work in a government office or nonprofit agency focus is on serving the community rather than building students' skills (Stasz \& Stern, 1998). Students gain skills and knowledge, while providing the community with a service, by combining community service with opportunities for reflection (National School to Work Office, 1999). Students are provided the opportunity for practice employability skills (Test et al., 2006).

Students attend professional speakers in their classroom to gather information about job expectations (Carter et al., 2010).

On-the-job work experience with various job sites through local business and organizations during the summer (Larson, 2011).

Tours of local businesses Students visit potential employers to gather information about job expectations (Carter et al., 2010).

\section{Apprenticeship or Internship for Specific Career}

High school student may participate in a variety of apprenticeship or intern programs related to a specific career. Through an apprenticeship students learn occupational skills related to a specific trade while under the supervision of an experienced worker (Lindstrom et al., 2012; Test et al., 2006). Occupational skills taught may include welding, electrician, carpentry, or plumbing. Programs provide students with in-depth skills training from a highly skilled employee (Lindstrom et al., 2012). Apprenticeship programs prepare students for high-skill employment (Lindstrom et al., 2012). Students can earn high school credits while receiving on-the-job training in a paid position (Scholl \& Mooney, 2004). Students continue to work with a company or business following graduation and often continue post-secondary education or training (Test et al., 2006). The goal of an internship is for the student to learn about the industry 
or occupation (Lemaire, Mallik, \& Stoll, 2002; Lindstrom et al., 2012; National School to Work Office, 1999). Students' placements are connected to their specific learning goals (Lindstrom et al., 2012). Students may work with job coaches or supervisors during their internship to develop work skills, habits, and behaviors and gain knowledge in a specific job area within a community setting (Lemaire et al., 2002; Lindstrom et al., 2012; Test et al., 2006). Internships provide students opportunity to develop employment skills and confidence (Tilson, Luecking, \& Donovan, 1994).

\section{Job Shadowing or Job Sampling}

Job shadowing or job sampling allows students to explore a range of jobs by observing a professional in specific occupations (Lindstrom et al., 2012). Students observe employees and develop an understanding of the environment and requirements of the job (Lindstrom et al., 2012; Test et al., 2006). Students have the opportunity to interact and ask questions of the employer and employees (Lindstrom et al., 2012). Students should reflect on their experiences to better determine their personal interests and abilities (Test et al., 2006). Reflection will give students insight into jobs they may or may not want to pursue (Lindstrom et al., 2012). Students determine what careers are of greatest interest to them (Nietupski et al., 2006). Job shadowing is an early structured work experience and is especially valuable to students who do not have job settings available (Lindstrom et al., 2012).

\section{Paid Job Outside of School Program}

Paid job outside of school program, or competitive employment, includes work experience with a public or private employer off-campus (Lindstrom et al.2012; Stasz \& Stern, 1998). The purpose of a paid work experience is for students to gain work 
experience, develop and practice employability skills, discover abilities, and foster an understanding of the benefits of hiring students with disabilities (Lindstrom et al., 2012; Sabbatino \& Macrine, 2007). Most often these job experiences are after school or on weekends and require involvement from the student, family, and possibly an adult service provider to obtain (Lindstrom et al., 2012; Test et al., 2006). Students' jobs are based on the training needs of the students but typically do not offer the same structure and support as other structured work experiences (Lindstrom et al., 2012; Test et al., 2006).

\section{Paid or Unpaid Job as Part of School Program}

Students engage in paid or unpaid work experiences in while supervised by school personnel. The students learn general work place skills (Lindstrom, 2014). These employment opportunities can provide students with a number of workplace experiences (Lindstrom, 2014). Jobs on-campus can provide students with the opportunity to improve work skills. Variables related such as supervision, pace, and interactions with others can be controlled while working at on-campus jobs (Test et al., 2006).

\section{School-Sponsored Enterprise or Youth-Run Business}

School-based enterprises or youth-run businesses require students to manage and work to produce goods or provide services for others within the school setting (Lindstrom et al., 2012; National School to Work Office, 1999; Stasz \& Stern, 1998). A student-run business provides students with opportunities to learn hands-on work and business skills (Lindstrom et al., 2012). Students develop leadership skills, build confidence, and prepare for the workforce by gaining an understanding of what it takes to run a business (Lindstrom et al, 2012). School-based enterprises are accessible to all students and allow schools that may not have extensive work-based experiences available, the opportunity to 
provide work experience to students while remaining on campus (Lindstrom et al., 2012).

\section{Service Learning or Volunteer Activities}

Service learning or volunteer work includes opportunities for students to work in the community, participating in hands-on volunteer projects (Lindstrom et al., 2012). Service learning opportunities are often driven by students' learning goals and meeting needs within the community (Lindstrom et al., 2012). Service learning experiences provide students with the opportunity to learn citizenship, teamwork, and leadership skills (Lindstrom et al., 2012). Though these experiences students will increase personal and social development (Lindstrom et al., 2012) and practice employment skills (Test et al., 2006). Students are provided with opportunities to apply skills that they have mastered in a supervised setting while learning and practicing new skills (Dymond, Renzaglia, \& Chun, 2008). Service learning projects should also include student reflection and analysis (Lindstrom et al., 2012; National School to Work Office, 1999).

\section{Summer Jobs}

Summer job opportunities are work experiences with local businesses and organizations throughout the summer months (Larson, 2011). Summer jobs provide students with short-term work experiences (Lindstrom et al., 2012). Students are able to participate in these experiences and not compete with academics or extracurricular activities (Lindstrom et al., 2012). Summer jobs provide basic training for occupational and social skills (Lindstrom et al., 2012). 


\section{Other Experiences: Career Days and Fairs, Speakers from Local Businesses, and Tours of Local Businesses}

Other introductory structured work experiences are career day or career fairs, speakers from local businesses, or tours of local businesses (Lindstrom et al., 2012). Each of these structured work experiences allow students the opportunity to explore and investigate careers and obtain in-depth information about career fields (Carter et al., 2010; Lemaire et al., 2002). At a school or local career day or career fair students meet with post-secondary educators, employers, employees, or human resource professionals to discuss their career interest and abilities (National School to Work Office, 1999). Students may also attend events with speakers from local businesses from professional speakers in their classroom or tour local businesses to gather information about job expectations.

\section{Structured Work Experience Programs}

A number of model high school career programs exist that integrate structure work experiences into their curriculum. The following are researched programs that focus on students' successful post-school employment outcomes: (a) High School/High Tech (Lemaire et al., 2002), (b) Bridges...from School to Work (Tilson, Luecking, \& Donovan, 1994), (c) Iowa's Super Senior program (Nietupski, 2006), (d) Start on Success (Sabbatino \& Macrine, 2007), (e) Wisconsin's Youth Apprenticeship Program (Scholl \& Mooney, 2004), and (f) Youth Transition Program (Benz, Lindstrom, Unruh, \&

Waintrup, 2004). These models meet the needs of a range of students. The overall goal of each program differs, but each focuses on improving students' employment outcomes. Features of these models include (a) career and transition planning; (b) academic, 
vocational, independent living, and personal-social instruction; (c) community based transition support, and (d) on-the-job training (Benz et al., 2004; Lemaire et al., 2002;

Nietupski et al., 2006; Sabbatino \& Macrine, 2007; Scholl \& Mooney, 2004; Tilson et al, 1994). Some of these programs were structured to reflect the importance of students having multiple and varied structured work experiences (Nietupski et al., 2006; Scholl \& Mooney, 2004). Structured work opportunities incorporated though these successful programs include (a) paid job training, (b) paid internship, (c) short term vocational experiences, (d) extended internships, and (e) entry level, paid positions (Benz et al., 2004; Nietupski et al., 2006; Sabbatino \& Macrine, 2007; Scholl \& Mooney, 2004; Tilson et al., 1994).

\section{Benefits of Structured Work Experiences}

Through structured work experiences students may have on the job opportunities to learn high-level technical skills (Stasz \& Stern, 1998). These skills could include (a) mastering procedures, (b) gaining an understanding of fundamental principles, (c) developing logical judgment, and (d) acquiring computer skills (Stasz \& Stern, 1998). Structured work experiences provide students the opportunity to develop personal and social skills including (a) initiative, (b) honesty, (c) teamwork, (d) work ethic, (e) work consistency, and (f) work responsibility (Kim \& Dymond, 2010; Lindstrom, et al., 2011; Stasz \& Stern, 1998). Students in structured work programs reported the work experiences that they had helped them to learn (a) to follow directions, (b) to get along with others, (c) to be responsible, (d) communication skills, and (e) to have desire to do well and learn (Stasz \& Stern, 1998). Teachers perceive the generalization of employment skills across settings as a benefit of structured work experiences (Kim and 
Dymond, 2010). Given opportunities to work in the community and apply knowledge in content students will deepen their understanding of work (Stasz \& Stern, 1998).

\section{Determination of Employment Preferences and Interests}

Structured work experiences provide students with the opportunity to be exposed to a variety of employment experiences and settings. Gaining work preferences and interests is a benefit of structured work experience (Lindstrom, Hirano, McCarthy, \& Alverson, 2014). Students have an opportunity to develop a foundation for choosing postschool employment (Lindstrom et al., 2011). Structured work experiences allow students to develop and practice occupational skills in a real world setting (Lindstrom et al., 2011). In a specialized setting more complex skills were learned and student confidence was built (Lindstrom et al., 2011).

\section{Dropout Prevention}

Special education teachers believe that skills and opportunities provided by structured work experiences increase the likelihood that students with disabilities will obtain paid employment and decrease high school dropout rates (Kim \& Dymond, 2010). The dropout prevention guide recommends that students have opportunities to participate in career academies, attend community speakers, participate in internships, or long-term employment to decrease dropout rates (Dynarski et al., 2008). Providing students with these types of opportunities encourages students to begin to think about career and other post-secondary options (Dynarski et al., 2008). Dunn, Chambers, and Rabren (2004) collected data from a post-school survey of students with disabilities who did and did not dropout of school. Results indicated that $80 \%$ of students who did not dropout felt that school prepared them for post-secondary opportunities. Of the students who dropped out, 
only $54 \%$ felt their program was preparing them for post-secondary opportunities they were interested in pursuing (Dunn et al., 2004). Martin et al. (2002) reviewed literature on dropout prevention and surveyed school administrators and other practitioners' perceptions on dropout interventions. They found the literature indicates that participation in school to work programs increased school success for students with and without disabilities (Martin et al., 2002). School administrators and other practitioners identified career exploration opportunities and school to work opportunities as practical and effective strategies to prevent high school dropouts (Martin et al., 2002).

\section{Preparation for Post-School Employment}

Structured work experience, community-based training that includes on-the-job training, and other career related activities build a foundation for post-school employment (Lindstrom et al., 2011; White \& Weiner, 2004). Kim and Dymond (2010) surveyed special education teachers with experience delivering vocational curriculum to examine perceptions related to structured work experiences, specifically community-based vocational instruction. The respondents rated a list of benefits of structured work experiences on how valuable they perceived the benefits were for high school students (Kim \& Dymond, 2010). Teacher perceived benefits of structured work experiences to include (a) students determining employment preferences by identifying vocational goals and employment interests, (b) preparation for students with disabilities for postsecondary outcomes, and (c) help to increase students' self-determination skills (Kim \& Dymond, 2010). Structured work experiences help students commit to improve (Stasz \& Stern, 1998), gain confidence to enter the workforce (Lindstrom et al., 2011), and gain independence (Lindstrom et al., 2014). Students develop career-planning skills through 
structured work experiences (Stasz \& Stern, 1998).

\section{Barriers to Effective Implementation of Structured Work Experiences}

All stakeholder groups in the transition process have recognized barriers to implementing structured work experiences. Surveys and interviews of these individuals indicate that a number of barriers to students with disabilities participating in structured work experiences are perceived. Five main themes related to barriers have emerged in the literature: (a) attitudes, (b) lack of support from school districts, (c) changes made in recent legislation, (d) lack of community access, and (e) student and parent participation.

\section{Attitudes}

Carter, Trainor et al. (2009) surveyed Chambers of Commerce and other employer networks to determine if employers think transition related activities are feasible for students. They found that employers perceive activities for students with disabilities to be less feasible. Chamber of Commerce members reported implementing activities less frequently with students with disabilities by $20 \%$ (Carter Trainor et al., 2009). Trainor et al. (2008) interviewed transition specialists and teachers of crosscategorical programs. The educational professionals perceived employers' attitudes related to students with disabilities as a barrier (Trainor et al., 2008). Carter and Hughes (2006) surveyed high school general and special education teachers, paraprofessionals, and administrators. These participants perceived a barrier to structured work experiences for students with disabilities as attitudes of high school teachers toward including students with disabilities (Carter \& Hughes, 2006). 


\section{Lack of Support from School Districts}

A lack of support from school districts can be a barrier to effective student participation in structured work experiences. These perceived school-based barriers include lack of (a) lack of administrator support (Kim \& Dymond, 2010), (b) insufficient staff (Kim \& Dymond, 2010; Wandry et al., 2008), (c) inadequate funding and financial support (Kim \& Dymond, 2010; Trainor et al., 2008; Wandry et al., 2008), (d) lack of preparation time (Kim \& Dymond, 2010), (e) lack of teacher training in transition-related skills (Wandry et al., 2008), and (f) transportation (Collet-Klingenberg \& Kolb, 2011; Carter et al., 2010). Unclear transition responsibilities between districts and limited educator knowledge or training in the area of transition are other factors limiting the effectiveness of structured work experiences (Li et al., 2009; Wandry et al., 2008). Other barriers perceived to affect student participation in structured work experiences include scheduling, accessibility of programs and curriculum, and availability of school-wide resources (Trainor et al., 2008; Wandry et al., 2008).

\section{Changes in Recent Legislation}

Additional barriers to structured work experiences are related to changes made in recent legislation. The increased focus on academics resulting from the requirements of No Child Left Behind (NCLB) have created barriers for effective structured work experiences for students with disabilities while in high school (Kim \& Dymond, 2010; Li et al., 2009). Challenges related to this legislation include pressure to (a) include students with disabilities in general education curriculum, (b) align standards-based content and vocational goals, and (c) include students with disabilities in high-stakes testing (Kim \& Dymond, 2010). 


\section{Limited Community Access}

Limited community access creates barriers to implementing structured work experiences. A limited number of employment opportunities for students with disabilities could result in students being placed in experiences based on convenience rather than on individual interests and goals (Collet-Klingenberg \& Kolb, 2011; Zhang et al., 2005). In a study of adolescents' career development activities during high school, Lindstrom et al. (2014) found that structured work experiences were often unpaid service industry jobs that were easy to find but did not provide exploration or training in a variety career options. The authors reported that these unpaid experiences resulted in post-school entry level, low-wage positions (Lindstrom et al., 2014). Schools and transition programs need to include a broad range of career exploration and work experience options (Lindstrom et al., 2014). A lack of employer accommodations creates a challenge to including students with disabilities in structured work experiences (Lindstrom et al., 2014).

Structured work experiences are limited for individuals with disabilities, especially students living in rural areas. Zhang, et al. (2005) also found that common transportation for a student in a rural area is school bus or personal transportation. These limitations on transportation may limit opportunities for structured work experiences.

\section{Student and Parent Participation}

Student and parent participation influence the effectiveness of structured work experiences. Students challenging behaviors, lack of student skill, severity of students' functional limitations, and lack of student involvement are perceived barriers to the effectiveness of community based career development (Kim \& Dymond, 2010; Wandry et al., 2008). Other family related perceived barriers include parent concerns and limited 
parent involvement (Kim \& Dymond, 2010).

\section{Recommended Structured Work Experience Practices}

Characteristics of effective structured work experience implementation have been identified in the literature. Scholars in the area have posited foundational principles for programs, a small number of studies have examined impact of specific characteristics, and other studies have examined perceptions of important characteristics. Five critical characteristics have been identified in this literature base: (a) opportunity to investigate a variety of career options, (b) integration of rigorous instruction and structured work experience, (c) incorporation of structured work experience into IEPs, (d) community experiences, and (e) parent engagement.

\section{Opportunity to Investigate a Variety of Career Options}

A variety of structured work experience opportunities should be made available to students with disabilities throughout high school. Students with disabilities should (a) have the opportunity to investigate a variety of career options (Lindstrom, Paskey et al., 2007), (b) participate in transition programs that focus on interest-job matching (EstradaHernandez et al., 2008; Lindstrom, Paskey et al., 2007), and (c) participate in a variety of structured work experiences during high school to build work skills (Lindstrom, Paskey et al., 2007; Zhang et al., 2005). Students should be given the opportunity to gain a deeper understanding of work though structured work experiences; this may be done by applying knowledge in contexts and putting their knowledge to use (Stasz \& Brewer, 1998).

Student employment success can be linked to transition programs that include early exploration of careers and connecting interests to student opportunities (Estrada- 
Hernandez et al., 2008). Kim and Dymond (2010) surveyed special education teachers about their perceptions of the importance of the components of structured work experiences and community-based instruction. Teachers reported that important components of structured work experiences and community-based instruction include that the students need to (a) perform different job tasks, (b) receive community-based instruction at least twice a week, and (c) have interaction with employees without disabilities (Kim \& Dymond, 2010).

\section{Integration of Rigorous Instruction and Structured Work Experience}

Schools should develop effective programs and opportunities that integrate academic learning and work experiences (Landmark et al., 2010). Kohler's (1996) Taxonomy for Transition Programming includes program structure, encouraging plans to include curricula that are outcome-based and integrated into a variety of settings. Carter et al., (2010) called for high school programs to integrate rigorous instruction with meaningful structured work experiences. Guy, Sitlington, Larsen, and Frank (2008) recommend school districts increase the number of courses and the models of delivery of structured work experiences. School staff should provide students with as many opportunities as feasible for job shadows, job site visits, guest speakers, and supported structured work experiences (Lindstrom, Paskey et al., 2007; Zhang et al., 2005). Kim and Dymond (2010) found teachers perceived classroom-based instruction prior to community participation to be an important component of structured work experiences and community-based instruction. 


\section{Incorporation of Structured Work Experience into IEPs}

Evidence-based secondary transition practices should be integrated into students' IEPs; including these practices will increase the likelihood that students will meet their post-school goals (Test, Mazzotti et al., 2009). Kohler's (1996) Taxonomy includes student-focused planning, addressing the importance of IEP development. It is recommended that post-secondary training goals are included in the IEP in a manner that addresses the individual personal needs of the student (Kohler, 1996). Structured work experiences should be included in a student's IEP (Guy et al., 2008). Teachers believe that collaboratively developing IEP goals for student is an important component of structured work experiences (Kim \& Dymond, 2010).

\section{Community Experiences}

Benz et al. (2000) found applied learning in the community to be an effective practice for preparing students with disabilities for post-secondary employment. Kohler (1996) recommended students participate in structured work experiences, including: (a) apprenticeships, (b) paid work experience, (c) work study program, and (d) job placement services. A review of literature by Test, Mazzotti, et al. (2009) found that community experiences were an evidence practice that supported employment-related post-school outcomes. Rowe et al. (2014) defined community experiences as "activities occurring outside the school setting, supported with in class instruction, where students apply academic, social, and/or general work behaviors and skills" (p. 8). For structured work experiences in the community to be successful, (a) communities need to be receptive of student employment experiences, (b) employment supports need to be available and recognized, and (c) employment experiences need to be meaningful to the student (Carter 
et al., 2009).

\section{Parent Engagement}

Schools should increase parent involvement by including parents in transition planning and educate parents about post-secondary employment and training options (Lindstrom et al., 2014). Information about training opportunities after high school should be made clear to families (Lindstrom, Doren, Metheny, Johnson, \& Zane, 2007). In a 2014 review of recent literature, Rowe et al. (2014) found evidence to support adding parent expectations as an additional predictor of successful post-school employment.

\section{Current Structured Work Experience Practices}

The implementation and availability of structured work experiences for student with disabilities is varied. Literature highlights the lack of implementation and availability of structured work experiences. Two themes emerged from the literature focusing on current practices related to structure work experiences: (a) general implementation of structured work experiences and (b) availability of structured work experiences for students with and without disabilities.

\section{Implementation of Structured Work Experiences}

Guy et al. (2008) examined employment preparation courses offered by 42 school districts in a Midwestern state. The authors found that $31.6 \%$ of all courses offered included an employment preparation component. Of the courses that included an employment preparation component $26.3 \%$ included a work-based experience $(6.5 \%$ work-based only and 19.8\% classroom- and work-based) (Guy et al., 2008). Of the workbased only courses, $74.3 \%$ were paid or unpaid work experiences, $6.0 \%$ were service learning, and $6.0 \%$ were school-based enterprises. Of the courses that combined 
classroom- and work-based experiences $30.7 \%$ were school-based enterprises, $19.0 \%$ were unpaid work experiences, $13.2 \%$ were job shadow, $11.2 \%$ were exploration, and 9.5\% were service learning methods (Guy et al., 2008).

Zhang et al. (2005) surveyed 105 teachers and 37 transition personnel to determine how involved school districts were involved in each transition practice. Teachers reported school-based work experiences (83.8\%), job shadowing (69.0\%), assistance from a job coach (55.6\%), volunteer work (55.6\%), service learning $(52.8 \%)$, and community-based training (52.1\%) were the most common experience (Zhang et al., 2005). Supported employment and internships were the least common structured work experiences (Zhang et al., 2005). Joshi et al. (2012) reported the frequency of employment-related transition activities accessed by students with mild intellectual disabilities from NLTS2 data. Structured work experiences included paid work experiences (59.7\%), school-sponsored work experiences (53.4\%), job shadowing (28.7\%), and internship or apprenticeship (9.4\%).

Research indicates that schools are implementing minimal structured work experiences for students, and the experiences available to students with disabilities are even more limited. An increase in structured work experiences for students with disabilities is needed (Carter et al., 2010). Guy et al. (2008) found that only $26.3 \%$ of employment preparation courses had a structured work component. Carter et al. (2010) found that schools are making efforts to prepare students for future careers through varied structured work experiences. In order for students with disabilities to achieve their postschool goals, efforts are needed by schools to create and deliver meaningful instruction and experiences related to career development (Carter et al., 2010). 


\section{Availability of Structured Work Experiences for Students With and Without Disabilities}

Carter et al. (2010) gathered data on the availability of structured work experiences from questionnaires completed by school-level representatives. Data were collected for students with and without disabilities. Results from the questionnaires indicated that structured work experience opportunities were offered to students with disabilities, but their participation in structured work experience varied (Carter et al., 2010). Schools are creating opportunities for students to promote skill development (Carter et al., 2010). A majority of school-level representatives reported schools offer career interest assessments, job-shadowing programs, interview and resume-writing practice, career related speakers, and career exploration courses as career development activities (Carter et al., 2010). However school-based enterprises, job placement services, and mentorship with an adult were the least available activities; these activities are beneficial to students with severe disabilities (Carter et al., 2010).

Zhang et al. (2005) surveyed middle and high school teachers and transition related personnel. The author reported that the following structured work experiences were most commonly implemented in schools: (a) school-based work experiences (83.8\%), (b) vocational/occupational courses $(74.6 \%)$, (c) receiving career information (73.9\%), (d) job shadowing (69.0\%), (e) assistance from a job coach (55.6\%), (f) volunteer work $(55.6 \%),(\mathrm{g})$ service learning $(52.8 \%)$, and $(\mathrm{h})$ community-based training (52.1\%) (Zhang et al., 2005). On the other hand structured work experiences least implemented in schools were supported employment (38.7\%) and internship (31.0\%) (Zhang et al., 2005). 
Carter et al. (2010) described the participation of students with disabilities in structured work experiences as generally uneven and fairly limited. Furthermore the authors found that very few students with severe disabilities participated in any of these activities (Carter et al., 2010). Zhang et al. (2005) found that student are often placed in convenient jobs, rather than matching their abilities and interests to the position. The most common work-based locations were grocery stores, fast food and other restaurants, retail stores, and the service industry (Zhang et al., 2005). Zhang, et al. (2005) also found that common transportation for a student in a rural area is school bus or personal transportation. These limitations on transportation may limit opportunities for structured work experiences.

Guy et al. (2008) recommended that research be to be completed to determine if students with disabilities access employment preparation courses differently from their general education peers. Repetto et al. (2011) examined students with and without disabilities perceptions of preparation for life after high school by collecting exit slips at the time of graduation at 40 high schools for two consecutive school years. There were differences reported between the preparations for two groups of students after high school. Differences were reported for who helped the students prepare, areas of student satisfaction, and job training (Repetto et al., 2011). Agency representatives, job coaches, and special education teachers were most likely to assist students with disabilities prepare, whereas friends/acquaintances, parents/family members, and themselves were most likely to assist students without disabilities (Repetto et al., 2011). Students without disabilities were satisfied with their preparation for post-secondary education, whereas students with disabilities were satisfied with their preparation for post-secondary 
employment (Repetto et al., 2011). Most students reported have job training experiences (Repetto et al., 2011). Students with disabilities were more likely to have jobs at school or as a requirement for a course, the opposite was true for students without disabilities, their jobs were most often not a course requirement and occurred in the community (Repetto et al., 2011). Overall $81 \%$ of all students reported that they enjoyed their current job (Repetto et al., 2011).

Students with disabilities should have the opportunity to participate in structured work experiences in the community. Students and individuals with disabilities work best in a typical work setting (Wehman, 2013). Wehman (2013) states that it should be a priority for all stakeholders to work together to achieve work opportunities that are best in the best interests of each student.

\section{Recommendations for Improving Access and Impact of Structured Work Experiences}

A review of the literature related to structure work experiences presents a number of recommendations for improvements to the current system. Recommendations are made for improvements to school districts and schools, school personnel, and employment consultants. Literature emphasizes the responsibilities of these different roles.

\section{School Districts}

Simonsen and Neubert (2012) stated that schools may need to restructure personnel and resources to make paid work experiences a part of students transition services. "Facilitating paid work experiences for student with intellectual and other developmental disabilities typically requires school systems to have transition specialists 
and/or job development specialists who have the expertise/skills to establish relationships with community business, identify potential employment opportunities, and develop accommodations/supports for the individual to work as independently as possible" (Simonsen \& Neubert, 2012, p. 196). Certo and Luecking (2011) recommend that IDEA be amended to allow schools to subcontract with post-school providers to allow students to work with these agencies to find jobs and learn community skills, so that these agencies are able to continue to support students after they exit from school.

\section{School Curriculum}

School-based personnel can address students' needs through structure work experience programs and curriculum (Hartman, 2009). School based personnel, including teachers and job coaches, should guide students with disabilities; facilitate career options; and provide opportunities for students to job shadow, visit job sites, and attend guest speakers (Lindstrom Paskey et al., 2007). Teachers and job coaches can address student needs, appropriate work behavior, and community behavior in community settings (Hartman, 2009).

Wehman (2013) recommended that teachers evaluate their curriculum to meet the needs of the students and the employers. Teachers should find out what is required in the business and industry workforce and look at their curriculum to determine if the skills, objectives, and activities relate to employers needs (Wehman, 2013). Guy et al. (2008) recommended that curriculum be changed to help prepare students for post-secondary employment. The responsibility to teach employment preparation curriculum should be distributed between core academic classes and career related courses (Guy et al., 2008). Evidence based predictors recommended by Test, Mazzotti et al. (2009) include offering 
occupational courses, vocational education opportunities, work-study opportunities, community experiences, and transition programs.

\section{Other}

Other recommended practices that need to occur when preparing individuals for employment after graduation include engaging families, creating earlier links between school and employment systems, and provide opportunities for individuals to build social connections during structured work experiences (Timmons, Hall, Bose, Wolfe, \& Winsor, 2011). Additional evidence based practices include self-determination/selfadvocacy, social skills, interagency collaboration, parental involvement, and parent expectations (Rowe et al., 2014; Test, Mazzotti et al, 2009).

\section{Structured Work Experiences in Rural Areas}

Teachers from rural schools face more and different barriers than teachers from urban schools in implementing structured work experiences (Kim \& Dymond, 2010). Students from an urban setting are 2.5 times more likely to have a job one year after high school than students from a rural school (Rabren et al., 2002). Paid employment experiences, transition services, and barriers to transition differ between urban and rural settings (Collet-Klingenberg \& Kolb, 2011; Joshi et al., 2012). Students with mild intellectual disabilities in urban areas are almost six times more likely than students in rural settings to have had a paid employment experience in school (Joshi, Bouck, \& Maeda, 2012). However, Joshi et al. (2012) did find that urban and rural students with mild intellectual disabilities participated in the same number of employment activities on average, but students educated in a suburban setting participated in a greater number of employment activities. Carter, Austin, and Trainor (2011) did not find a strong 
association between paid work experience and community type for individuals with severe disabilities. They found the availability of accessible transportation to be the only predictor of work experience (Carter et al., 2011).

Rural school districts offer very few vocational opportunities, either in and out of school, for students with disabilities (Arnold, Seekins, \& Nelson, 1997; ColletKlingenberg \& Kolb, 2011). Teachers have reported that there is a lack of work experience sites for individuals with disabilities and lack of time to coordinate and plan work experiences (Kim \& Dymond, 2010). Rural communities also lack (a) time for job development, (b) supervision when students are able to obtain work in the community, and (c) transportation options (Collet-Klingenberg \& Kolb, 2011). Increased competition for the limited job opportunities magnifies these barriers (Collet-Klingenberg \& Kolb, 2011). Other barriers to community job development opportunities in rural areas include lower education levels and higher unemployment rates (Arnold et al., 1997). The limited or complete lack of public transportation, lack of mobility for students with disabilities in rural areas, and lack of funding for transition services limits school-community instruction (Arnold et al., 1997; Collet-Klingenberg \& Kolb, 2011).

Past research has provided guidelines for implementing structured work experience opportunities to students in rural communities. As is recommended for all students with disabilities, the transition process in rural communities should focus on students' preferences and self-determination (Morgan \& Morgan, 2006). Students in rural setting may need to focus efforts for support systems differently; they could contact and develop support systems in the community through family, neighbors, churches, social groups, and civic organizations to identify possible job opportunities (Collet-Klingenberg 
\& Kolb, 2011; Morgan \& Morgan, 2006). These support systems could assist in student transportation to community career development opportunities (Collet-Klingenberg \& Kolb, 2011; Morgan \& Morgan, 2006).

Identifying employment opportunities for students in rural communities can be a challenging task. Research recommends that students participate in identifying employment opportunities by (a) keeping up-to-date with new and existing businesses by reading local newspapers, (b) building relationships with business owner and identify employer needs by touring the business, and (c) learning about current positions, job requirements, and job turnover by talking with current employees (Morgan \& Morgan, 2006). Collet-Klingenberg and Kolb (2011) recommend that schools collaborate with other local schools and business in nearby communities to pool resources. Teachers in rural communities should be prepared to focus job development on both rural ecology and student preferences as well as be prepared to modify jobs to meet student and employer needs (Morgan \& Morgan, 2006).

Teachers and school personnel face different challenges when implementing structured work experiences in a rural area. In rural areas there are fewer opportunities for students to participate in structured work experiences (Arnold et al., 1997; ColletKlingenberg \& Kolb, 2011). Other challenges rural areas face are increased competition related to limited job opportunities (Collet-Klingenberg \& Kolb, 2011) and higher unemployment rates (Arnold et al., 1997). Additional barriers include lack of public transportation and funding for transition services (Arnold et al., 1997; Collet-Klingenberg \& Kolb, 2011). 


\section{Gaps in Research and Research Questions}

Prior research supports the positive influence structured work experiences can have on student's post-school employment outcomes (Benz et al., 2000; Joshi et al., 2012; Lindstrom et al., 2011; Nietupski et al., 2006; Rabren et al., 2002; Simonsen \& Neubert, 2012). Previous research has identified best practices related to student employment preparation. Many of these best practices fall under the umbrella term structured work experience. Research has identified many benefits related to structured work experiences, however research is limited on teachers' perspectives regarding the frequency, availability, and effectiveness of structure work experiences offered to students with disabilities in their rural high school. Research is also limited on perceptions of high school special education teachers have on the value of, impact of, and barriers to implementation of structured work experiences for students with disabilities in rural school districts. The proposed study will provide a current examination of the availability of and perspectives on structured work experiences in rural schools, reflecting the state of such transition activities in the current education reform and economic contexts.

The following research questions will be addressed:

1. What are rural special education teachers' perceptions of the (a) benefit of, (b) frequency of participation in, and (c) quality of implementation of structured work experiences?

2. What are rural special education teachers' perceptions of the significance of barriers to implementation of structured work experiences? 


\section{CHAPTER III}

\section{METHOD}

This research design was a quantitative survey questionnaire to describe trends in the perspectives of high school special education teachers, transition specialists, and other personnel related to structured work experiences.

\section{Survey Instrument}

A survey was developed specifically for this study. Survey items were developed based on a review of prior research. Specifically, both surveys and findings from Carter et al. (2010), Kim \& Dymond (2010), Lindstrom, Doren, Flannery, \& Benz (2011), and Zhang et al. (2005) were used to generate key sections of my survey. Specific items in my survey were drawn from research on barriers, benefits, and types of structured work experiences. Below is a description of how this research was used to develop this survey.

Survey items related to specific structured work experience activities include activities that have been demonstrated to be predictors of post school employment, including paid work, and summer employment (as a form of paid work) (Benz, Yovanoff, \& Doren, 1997). Additional structured work experience activities were drawn from research on implementation and include: (a) apprenticeships (Carter et al., 2010; Lindstrom et al., 2011), (b) career days and career fairs (Carter et al., 2010), (c) internships (Carter et al., 2010; Lindstrom et al., 2011; Zhang et al., 2005), (d) job shadows and job samples (Carter et al., 2010; Lindsrom et al.), (e) school based 
enterprises (Carter et al.; Lindstrom et al.; Zhang et al.), (f) service learning or volunteering (Lindstrom et al.; Zhang et al.), (g) speakers from local businesses (Carter et al.), and tours of local businesses (Carter et al.).

Survey items were also derived from Kim \& Dymond's (2010) study of benefits, barriers, and components of community-based vocational instruction (CBVI). Benefits identified in their study were included in the development of this study's survey questions related to determining the impact that structure work experiences have on student outcomes. Benefits included were (a) increased students' independence, (b) increase on employment outcomes for students, and (c) decrease of high school dropout rates. Additionally the following barriers included in Kim and Dymond's survey were included in this survey: (a) limited number of staff, (b) limited funding, (c) requirements to include all students in high-stakes testing, (d) student behavior, (e) lack of time to prepare, (f) lack of transportation, (g) limited teacher experiences, (h) severity of student's disability, (i) inclusion of students with disabilities in general education curriculum, (j) alignment of standard-based content and vacation goals, and (k) lack of support from administration.

Sections I and II of the survey include items related to teacher (respondent) and school characteristics, respectively. Section III of the survey assesses respondents' perceptions of the benefit, frequency, and implementation of 11 specific structured work experiences. Section IV of the survey assesses respondents' perceptions of the significance of barriers related to implementation of structured work experiences. Section V gathers information on respondents' perceptions of the impact of structured work experiences overall. Section VI addresses respondents' preparation for delivering 
structured work experiences.

Six-point Likert-like scales similar to those used by Kim and Dymond (2010) are used in Sections III, IV, and V, with anchors labeled in relation to the stem for each section $(1=$ not beneficial to $6=$ extremely beneficial; $1=$ no students with disabilities participate to $6=$ all students with disabilities participate, $1=$ poor implementation to 6 $=$ excellent implementation; $1=$ not a barrier to $6=$ extreme barrier; $1=$ no influence to $6=$ extreme influence).

A draft of the survey was piloted and reviewed with three experts in school career development expertise. Two reviewers were coordinators of special education career development programs at non-rural schools as well as completers of the Illinois State University Transition Specialist Graduate Certificate program. The third was a director of career and technical education for a large urban high school. A link to the survey was emailed to six potential pilot participants. Participants were asked to complete the survey as well as to provide feedback on the clarity and validity of the survey. At the end of the survey, additional items were added that requests feedback for the survey. Feedback from the pilot was used to revise the survey. The survey instrument is in Appendix A.

\section{Participants}

The sample for this research study was drawn from rural high school special education teachers and related personnel who teach students with disabilities. Rural status of schools was identified based on the New Urban-Centric Locale Codes (National Center for Educational Statistics, 2006). The New Urban-Centric Locale Codes were changed in 2005 and 2006 and are based on a school districts proximity to an urbanized area (National Center for Educational Statistics). Schools that meet the criteria of (a) 
Rural, Fringe; (b) Rural, Distant; or (c) Rural, Remote were identified as eligible for this study. The National Center for Educational Statistics (2006) defines those locale codes as:

Rural, fringe: census-defined rural territory that is less than or equal to 5 miles from an urbanized area, as well as rural territory that is less than or equal to 2.5 miles from an urban cluster

Rural, distant: census-defined rural territory that is more than 5 miles but less than or equal to 25 miles from an urbanized area, as well as rural territory that is more than 2.5 miles but less than or equal to 10 miles from an urban cluster"

Rural, remote: census-defined rural territory that is more than 25 miles from an urbanized area and is also more than 10 miles from an urban cluster

(National Center for Educational Statistics, 2006)

The Census Bureau identifies two types of urban areas: Urbanized Areas and Urban Clusters. Urbanized Areas are areas of 50,000 or more people, and Urban Clusters are areas of at least 2500 and less than 50,000 people (United States Census Bureau, 2015). "Rural" encompasses all population, housing, and territory not included within an urban area (United States Census Bureau, 2015).

A total of 33 rural, fringe; 135 rural, distant; and 46 rural, remote high school districts in the state of Illinois were identified (Illinois State Board of Education, 2015). For each of these school districts, principals' e-mail addresses were located using web based searches. Convenience sampling was used to collect data from town and rural high 
school special education teachers and related personnel.

\section{Procedures}

Principals were emailed and asked to forward the cover letter with survey link to staff members who were special education teachers, vocational or work coordinators, and transition specialist. A follow up email was sent to administrators two weeks later with another request to forward the survey information and link.

The cover letter sent to the school personnel via the principals asked them to participate in an online survey regarding their perceptions of structured work experiences. Teachers and related personnel were reminded that their participation was not required, but their perceptions of the benefits, barriers, and implementation of structured work experiences would be appreciated as important data for this study. The potential respondents were provided with a link to the survey via the initial e-mail forwarded from their principal. A two-week time frame was provided before a follow-up e-mail request is sent to principals asking them to again forward the email on to all high school special education teachers, vocational or work coordinators, and transition specialists within their school district.

\section{Data Analysis}

Data were imported from Select Survey into Excel. Descriptive statistics (frequencies, percentages, means, and standard deviations) were used to summarize data (e.g., frequencies, percentages, means, and standard deviations). Due to the small sample size and the unequal distribution across demographic variables, the intended inferential statistical analysis was not completed. Analysis of variance was used to explore significant differences of means among groups related to both teacher and school 
characteristics.

\section{Participants Demographics}

A total of 51 surveys were returned. Of those returned surveys, only 39 were used when determining results. Surveys were not included in analysis either because respondents replied "no" to the consent question, which is at the beginning of the survey, or because the survey was not completed past the demographic section. Table 2 presents a summary of demographic characteristics of the 39 respondents included in analysis.

Two demographic questions contained "other" responses. For highest degree earned, one respondent indicated they had earned two masters degrees and another indicated they had a bachelors plus additional credit hours. For response related to the field of bachelor degree, "other" responses included: a therapeutic recreation, two elementary education, two social science history with LBS1, a psychology, two math education, and two social science education, history degrees.

The survey also included questions on teacher experience and preparation with structured work experiences. Twenty-four of the respondents had experience developing and implementing structured work experiences. One teacher did not respond with their experience. Fewer respondents felt that they were prepared to provide structured work experiences. Six respondents felt they were not at all prepared, and 20 felt that they were somewhat prepared to provide structured work experiences. Eleven respondents were moderately prepared and only one teacher was very prepared. More teachers felt that they were prepared to incorporate structured work experiences into academic content. One respondent again felt they were very prepared, and 14 teachers felt moderately prepared to incorporate structured work experiences into academic content. Only 18 teachers felt 
somewhat prepared and five felt not at all prepared to incorporate structured work experiences.

Table 2

Demographics of Participants

\begin{tabular}{|c|c|c|c|}
\hline Demographic & & $f$ & $\%$ \\
\hline \multicolumn{4}{|l|}{ Gender $(n=39)$} \\
\hline & Male & 3 & 7.69 \\
\hline & Female & 36 & 92.31 \\
\hline \multicolumn{4}{|c|}{ Years of Teaching Experience $(n=38)$} \\
\hline & $0-5$ & 10 & 26.32 \\
\hline & $6-10$ & 9 & 23.68 \\
\hline & $11-15$ & 7 & 18.42 \\
\hline & $16-20$ & 5 & 13.16 \\
\hline & $21+$ & 1 & 2.63 \\
\hline \multicolumn{4}{|c|}{ Primary job classification $(n=39)$} \\
\hline & $\begin{array}{l}\text { Special education } \\
\text { teacher }\end{array}$ & 38 & 97.44 \\
\hline & Math teacher & 1 & 2.56 \\
\hline \multicolumn{4}{|c|}{ Highest degree earned $(n=39)$} \\
\hline & Bachelors & 22 & 56.41 \\
\hline & Masters & 14 & 35.90 \\
\hline & Doctorate & 1 & 2.56 \\
\hline & Other & 2 & 5.13 \\
\hline \multicolumn{4}{|c|}{ Bachelors degree field $(n=38)$} \\
\hline & Special education & 26 & 68.42 \\
\hline & Vocational & 1 & 2.63 \\
\hline & Other & 11 & 28.95 \\
\hline \multicolumn{4}{|c|}{ Grade levels taught $(n=39)$} \\
\hline & 9 & 38 & 97.44 \\
\hline & 10 & 37 & 94.87 \\
\hline & 11 & 35 & 89.74 \\
\hline & 12 & 34 & 87.18 \\
\hline & $12+$ & 7 & 17.95 \\
\hline \multicolumn{4}{|c|}{ Most frequent disability category of students $(n=38)$} \\
\hline & $\begin{array}{l}\text { Specific learning } \\
\text { disability }\end{array}$ & 26 & 68.42 \\
\hline & $\begin{array}{l}\text { Emotional and } \\
\text { behavioral disorders }\end{array}$ & 0 & \\
\hline & Intellectual disability & 2 & 5.26 \\
\hline & Autism & 0 & \\
\hline
\end{tabular}




\begin{tabular}{lll} 
Multiple disabilities & 8 & 21.05 \\
$\begin{array}{l}\text { Other health } \\
\text { impairments }\end{array}$ & 2 & 5.26 \\
$\begin{array}{l}\text { Students without } \\
\text { disabilities }\end{array}$ & 0 & \\
\hline
\end{tabular}

Time devoted to transition related responsibilities each week $(n=39)$

$\begin{array}{lll}<2 \text { hours } & 15 & 38.46 \\ 2-5 \text { hours } & 14 & 35.90 \\ 6-10 \text { hours } & 7 & 17.95 \\ 10+\text { hours } & 3 & 7.69\end{array}$

\section{School Characteristics}

Respondents were also asked about programs their schools offer. Programs included Career and Technical Education (CTE), Secondary Transitional Experience Program (STEP), and community service as a graduation requirement. Twenty-one of the teachers responded that their schools had a CTE program, however four respondents did not know and one did not respond. Out of the surveys used in analysis, 32 responded that their school did have STEP; three did not know if their school had this program. Only six of the respondents' schools required community service as a graduation requirement.

Table 3

School Characteristics

Characteristic f

$\%$

\begin{tabular}{cll}
\hline Students enrolled in high school $(n=39)$ & 1 & \\
$<100$ & 17 & 2.56 \\
$101-300$ & 10 & 43.59 \\
$301-500$ & 6 & 25.64 \\
$501-700$ & 1 & 15.38 \\
$701-900$ & 4 & 2.56 \\
$901+$ & 10 & 10.26 \\
\hline Student receiving special education services $(n=39)$ & \\
$0-25$ & 15 & 25.64 \\
$26-50$ & 8 & 38.46 \\
$51-75$ & 2 & 20.51 \\
$76-100$ & 4 & 5.13 \\
$100+$ & & 10.26 \\
\hline
\end{tabular}




\section{CHAPTER IV}

\section{RESULTS}

Data were collected through the online survey, Survey on Structured Work Experiences in Rural Schools for Students with Disabilities. Reponses from 39 high school special education teachers, transition specialists, and other related personnel are presented in this chapter. Due to the limited number of survey responses, only descriptive statistics are presented.

Results will be organized by original research questions, followed by additional findings. Data on perceptions of the importance, frequency, and impact of structured work experiences as well as on barriers to implementation are presented.

\section{Research Question 1: Importance, Frequency of Participation, and Quality of Implementation of Structured Work Experiences}

\section{Importance of Structured Work Experiences}

The first research question examined "What are rural special education teachers' perceptions of the (a) benefit of, (b) frequency of participation in, and (c) quality of implementation of structured work experiences?" Importance was examined from three angles. First, respondents were asked to rate the benefit of each activity to student development. Second, respondents were asked to rate the influence of structured work activities on specific outcome areas. Third, respondents were asked to identify the most appropriate grade level for implementation of each activity; in other words, at which point in transition experiences is a structured work experience most beneficial to students 
with disabilities.

Benefit to student development. Respondents rated how beneficial each of the ten specific structured work experiences is for students with disabilities using a six-point scale, with one being "not beneficial" and six being "extremely beneficial." Table 4 presents a summary of this data. Of the ten activities, three had a mean of five or above: apprenticeship for a specific career, job shadowing, and paid or unpaid job as part of the school program. Respondents' perceived school sponsored enterprises and speakers from local businesses to be the least beneficial of the activities.

More than $50 \%$ of respondents perceived apprenticeships for a specific career to be extremely beneficial (i.e., rated it as a six). An additional six of the activities were rated as a five or a six by over $50 \%$ of respondents, including: job shadows, paid job outside of school program, paid or unpaid job as part of school program, service learning, summer job, and tours of businesses. Only four "not beneficial" responses were made: one for paid job outside of school program, two for school-sponsored enterprises, and one for speakers from businesses. Overall, data indicate that respondents view a variety of structured work experiences to be beneficial to students with disabilities.

Influence on post-school outcomes. Respondents also rated the influence of structured work experiences on five outcome areas: high school completion, attendance at a four-year college or university, attendance at a community college, employment post high school, and independent living. In this section, respondents did not rate specific activities but rather the influence of structured work experiences as a whole on outcomes. Ratings were on a six-point scale, with one being "no influence" and six being "extreme influence." Data is summarized in Table 5. Responses indicate that structured work 
Table 4

Ratings of the Importance of Specific Structured Work Experiences

\begin{tabular}{|c|c|c|c|c|c|c|c|c|}
\hline $\begin{array}{l}\text { Structured work } \\
\text { experience }\end{array}$ & $1(\%)$ & $2(\%)$ & $3(\%)$ & $4(\%)$ & $5(\%)$ & $6(\%)$ & $M$ & $S D$ \\
\hline $\begin{array}{l}\text { Apprenticeship or } \\
\text { internship for specific } \\
\text { career }(n=38)\end{array}$ & $0(0.0)$ & $1(2.6)$ & $2(5.3)$ & $4(10.5)$ & $11(29.0)$ & $20(52.6)$ & 5.24 & 1.02 \\
\hline $\begin{array}{l}\text { Career days or career } \\
\text { fairs }(n=39)\end{array}$ & $0(0.0)$ & $2(5.1)$ & $3(7.7)$ & $15(38.5)$ & $8(20.5)$ & $11(28.2)$ & 4.59 & 1.14 \\
\hline $\begin{array}{l}\text { Job shadowing or job } \\
\text { sampling }(n=39)\end{array}$ & $0(0.0)$ & $0(0.0)$ & $4(10.3)$ & $2(5.1)$ & $16(41.0)$ & $17(43.6)$ & 5.18 & 0.94 \\
\hline $\begin{array}{l}\text { Paid job outside of } \\
\text { school program }(n=39)\end{array}$ & $1(2.6)$ & $1(2.6)$ & $6(15.4)$ & $7(18.0)$ & $11(28.2)$ & $13(33.3)$ & 4.67 & 1.30 \\
\hline $\begin{array}{l}\text { Paid or unpaid job as } \\
\text { part of school program } \\
(n=38)\end{array}$ & $0(0.0)$ & $0(0.0)$ & $4(10.5)$ & $7(18.4)$ & $12(31.6)$ & $15(39.5)$ & 5.00 & 1.01 \\
\hline $\begin{array}{l}\text { School-sponsored } \\
\text { enterprise or Youth-run } \\
\text { business }(n=38)\end{array}$ & $2(5.3)$ & $3(7.9)$ & $12(31.6)$ & $7(18.4)$ & $8(21.0)$ & $6(15.8)$ & 3.89 & 1.41 \\
\hline $\begin{array}{l}\text { Service learning or } \\
\text { volunteer activities ( } n= \\
38 \text { ) }\end{array}$ & $0(0.0)$ & $2(5.3)$ & $3(7.9)$ & $6(15.8)$ & $13(34.2)$ & $14(36.8)$ & 4.89 & 1.58 \\
\hline $\begin{array}{l}\text { Speakers from local } \\
\text { businesses }(n=39)\end{array}$ & $1(2.6)$ & $4(10.3)$ & $7(18.0)$ & $12(30.8)$ & $9(23.1)$ & $6(15.4)$ & 4.08 & 1.31 \\
\hline Summer jobs $(n=38)$ & $0(0.0)$ & $0(0.0)$ & $3(7.9)$ & $12(31.6)$ & $14(36.8)$ & $9(23.7)$ & 4.76 & 0.91 \\
\hline $\begin{array}{l}\text { Tours of local } \\
\text { businesses }(n=38)\end{array}$ & $0(0.0)$ & $3(7.9)$ & $7(18.4)$ & $9(23.7)$ & $10(26.3)$ & $9(23.7)$ & 4.39 & 1.26 \\
\hline
\end{tabular}

Note. $1=$ Not beneficial; $6=$ Extremely beneficial. 
experiences are seen as having the greatest influence on employment post high school and independent living and the least influence on outcomes related to post-secondary education.

Table 5

Ratings of the Influence Structured Work Experiences have on Specific Post-School Outcomes

\begin{tabular}{|c|c|c|c|c|c|c|c|c|}
\hline $\begin{array}{c}\text { Post- } \\
\text { secondary } \\
\text { outcome }\end{array}$ & $1(\%)$ & $2(\%)$ & $3(\%)$ & $4(\%)$ & $5(\%)$ & $6(\%)$ & $M$ & $S D$ \\
\hline $\begin{array}{l}\text { High school } \\
\text { completion } \\
(n=38)\end{array}$ & $\begin{array}{l}6 \\
(15.8)\end{array}$ & $\begin{array}{l}3 \\
(7.9)\end{array}$ & $\begin{array}{l}4 \\
(10.5)\end{array}$ & $\begin{array}{l}2 \\
(5.3)\end{array}$ & $\begin{array}{l}10 \\
(26.3)\end{array}$ & $\begin{array}{l}13 \\
(34.2)\end{array}$ & 4.21 & 1.88 \\
\hline $\begin{array}{l}\text { Attendance } \\
\text { at four-year } \\
\text { college or } \\
\text { university } \\
(n=38)\end{array}$ & $\begin{array}{l}6 \\
(15.8)\end{array}$ & $\begin{array}{l}5 \\
(13.2)\end{array}$ & $\begin{array}{l}9 \\
(23.7)\end{array}$ & $\begin{array}{l}10 \\
(26.3)\end{array}$ & $\begin{array}{l}6 \\
(15.8)\end{array}$ & $\begin{array}{l}2 \\
(5.3)\end{array}$ & 3.29 & 1.45 \\
\hline $\begin{array}{l}\text { Attendance } \\
\text { at } \\
\text { community } \\
\text { college } \\
(n=38)\end{array}$ & $\begin{array}{l}3 \\
(7.9)\end{array}$ & $\begin{array}{l}5 \\
(13.2)\end{array}$ & $\begin{array}{l}7 \\
(18.4)\end{array}$ & $\begin{array}{l}7 \\
(18.4)\end{array}$ & $\begin{array}{l}11 \\
(29.0)\end{array}$ & $\begin{array}{l}5 \\
(13.2)\end{array}$ & 3.87 & 1.52 \\
\hline $\begin{array}{l}\text { Employment } \\
\text { post high } \\
\text { school } \\
(n=38)\end{array}$ & $\begin{array}{l}1 \\
(2.6)\end{array}$ & $\begin{array}{l}0 \\
(0.0)\end{array}$ & $\begin{array}{l}1 \\
(2.6)\end{array}$ & $\begin{array}{l}9 \\
(23.7)\end{array}$ & $\begin{array}{l}16 \\
(42.1)\end{array}$ & $\begin{array}{l}11 \\
(29.0)\end{array}$ & 4.89 & 1.03 \\
\hline $\begin{array}{l}\text { Independent } \\
\text { living } \\
(n=37)\end{array}$ & $\begin{array}{l}2 \\
(5.4)\end{array}$ & $\begin{array}{l}0 \\
(0.0)\end{array}$ & $\begin{array}{l}3 \\
(8.1)\end{array}$ & $\begin{array}{l}9 \\
(24.3)\end{array}$ & $\begin{array}{l}11 \\
(29.7)\end{array}$ & $\begin{array}{l}12 \\
(32.4)\end{array}$ & 4.70 & 1.31 \\
\hline
\end{tabular}

Note. $1=$ No influence; $6=$ Extreme influence.

Appropriate grade level for participation. Responses related to grade level appropriateness are summarized in Table 6 . Respondents indicated that most structured work experiences would most appropriately be participated in during either early or late high school. The exception was service learning or volunteer activities, which were most frequently rated as appropriate for middle school. A higher percentage of respondents 
indicated that career days or career fairs, tours of local businesses, and job shadowing or job sampling would most appropriately be participated in during early high school.

Apprenticeships for specific careers and paid jobs outside of school programs were rated highest for late high school participation.

Table 6

Ratings of the Grade Level Appropriateness of Specific Structured Work Experiences

\begin{tabular}{|c|c|c|c|}
\hline $\begin{array}{l}\text { Structured work } \\
\text { experiences }\end{array}$ & $\begin{array}{c}\text { Middle school } \\
f(\%)\end{array}$ & $\begin{array}{c}\text { Early high school } \\
f(\%)\end{array}$ & $\begin{array}{c}\text { Late high school } \\
f(\%)\end{array}$ \\
\hline $\begin{array}{l}\text { Apprenticeship or } \\
\text { internship for specific } \\
\text { career }(n=39)\end{array}$ & $1(2.6)$ & $7(18.0)$ & $31(79.5)$ \\
\hline $\begin{array}{l}\text { Career days or career } \\
\text { fairs }(n=38)\end{array}$ & $7(18.4)$ & $23(60.5)$ & $8(21.0)$ \\
\hline $\begin{array}{l}\text { Job shadowing or job } \\
\text { sampling }(n=39)\end{array}$ & $1(2.6)$ & $22(56.4)$ & $16(41.0)$ \\
\hline $\begin{array}{l}\text { Paid job outside of } \\
\text { school program }(n= \\
39)\end{array}$ & $0(0.0)$ & $9(23.1)$ & $30(76.9)$ \\
\hline $\begin{array}{l}\text { Paid or unpaid job as } \\
\text { part of school } \\
\text { program }(n=37)\end{array}$ & $1(2.7)$ & $16(43.2)$ & $20(54.0)$ \\
\hline $\begin{array}{l}\text { School-sponsored } \\
\text { enterprise or Youth- } \\
\text { run business }(n=39)\end{array}$ & $6(15.4)$ & $19(48.7)$ & $14(35.9)$ \\
\hline $\begin{array}{l}\text { Service learning or } \\
\text { volunteer activities ( } n \\
=39 \text { ) }\end{array}$ & $17(43.6)$ & $14(35.9)$ & $8(20.5)$ \\
\hline $\begin{array}{l}\text { Speakers from local } \\
\text { businesses }(n=39)\end{array}$ & $12(30.8)$ & $20(51.3)$ & $7(18.0)$ \\
\hline Summer jobs $(n=38)$ & $1(2.6)$ & $16(42.1)$ & $21(55.3)$ \\
\hline $\begin{array}{l}\text { Tours of local } \\
\text { businesses }(n=39)\end{array}$ & $11(28.2)$ & $23(59.0)$ & $5(12.8)$ \\
\hline
\end{tabular}

\section{Frequency of Participation by Students with Disabilities}

Respondents rated the frequency of participation by students with disabilities in each of the structured work experiences as part of their transition activities. Ratings were 
Table 7

Rating of the Frequency of Participation of Students with Disabilities in Specific Structured Work Experiences

\begin{tabular}{|c|c|c|c|c|c|c|c|c|}
\hline $\begin{array}{l}\text { Structured work } \\
\text { experience }\end{array}$ & $1(\%)$ & $2(\%)$ & $3(\%)$ & $4(\%)$ & $5(\%)$ & $6(\%)$ & $M$ & $S D$ \\
\hline $\begin{array}{l}\text { Apprenticeship or } \\
\text { internship for specific } \\
\text { career }(n=39)\end{array}$ & $10(25.6)$ & $10(10.6)$ & $13(33.3)$ & $2(5.1)$ & $4(10.3)$ & $0(0.0)$ & 2.49 & 1.23 \\
\hline $\begin{array}{l}\text { Career days or career } \\
\text { fairs }(n=38)\end{array}$ & $3(7.9)$ & $3(7.9)$ & $6(15.8)$ & $10(26.3)$ & $7(18.4)$ & $9(23.7)$ & 4.11 & 1.54 \\
\hline $\begin{array}{l}\text { Job shadowing or job } \\
\text { sampling }(n=39)\end{array}$ & $6(15.4)$ & $8(20.6)$ & $9(23.1)$ & $6(15.4)$ & $4(10.3)$ & $6(15.4)$ & 3.31 & 1.66 \\
\hline $\begin{array}{l}\text { Paid job outside of } \\
\text { school program }(n=39)\end{array}$ & $3(7.7)$ & $7(18.0)$ & $18(46.2)$ & $7(18.0)$ & $4(10.3)$ & $0(0.0)$ & 3.05 & 1.05 \\
\hline $\begin{array}{l}\text { Paid or unpaid job as } \\
\text { part of school program } \\
(n=38)\end{array}$ & $7(18.4)$ & $9(23.7)$ & $11(28.9)$ & $7(18.4)$ & $4(10.5)$ & $0(0.0)$ & 2.79 & 1.26 \\
\hline $\begin{array}{l}\text { School-sponsored } \\
\text { enterprise or Youth-run } \\
\text { business }(n=39)\end{array}$ & $22(56.4)$ & $4(10.2)$ & $8(20.5)$ & $4(10.3)$ & $1(2.6)$ & $0(0.0)$ & 1.92 & 1.20 \\
\hline $\begin{array}{l}\text { Service learning or } \\
\text { volunteer activities }(n= \\
38)\end{array}$ & $7(18.4)$ & $9(23.7)$ & $12(31.6)$ & $4(10.5)$ & $3(7.9)$ & $3(7.9)$ & 2.89 & 1.47 \\
\hline $\begin{array}{l}\text { Speakers from local } \\
\text { businesses }(n=39)\end{array}$ & $8(20.5)$ & $6(15.4)$ & $9(23.1)$ & $8(20.5)$ & $2(5.1)$ & $6(15.4)$ & 3.21 & 1.67 \\
\hline Summer jobs $(n=39)$ & $2(5.1)$ & $6(15.4)$ & $21(53.8)$ & $5(12.8)$ & $5(12.8)$ & $0(0.0)$ & 3.13 & 1.00 \\
\hline $\begin{array}{l}\text { Tours of local } \\
\text { businesses }(n=39)\end{array}$ & $10(25.6)$ & $8(20.5)$ & $9(23.1)$ & $8(20.5)$ & $2(5.1)$ & $2(5.1)$ & 2.74 & 1.45 \\
\hline
\end{tabular}

Note. 1 = No students with disabilities participate; $6=$ All students with disabilities participate. 
on a scale of one to six, one being "no students with disabilities participate" and six being “all students with disabilities participate." Table 7 presents a summary of this data. Data indicate that the highest proportion of students with disabilities participate in career days. Job shadows, speakers from local businesses, summer jobs, and paid jobs outside of school programs were also rated relatively high in frequency of participation. Schoolsponsored enterprises and apprenticeships had the lowest frequency ratings.

Data indicate that career days were the only structured work experience with a mean over half for student participation. More than $50 \%$ of respondents reported that no students were participating in school-sponsored enterprises. Apprenticeships and tours of local businesses had more than $25 \%$ of respondents replied that no students participate in these structured work experiences within their school.

\section{Comparison Between Importance and Frequency Ratings}

Respondents' ratings of the importance of specific structured work experiences did not always align with their ratings of the frequency of student participation in those activities. Table 8 presents summary data of this comparison. Apprenticeships for specific careers was rated the most beneficial structured work experience, but in frequency the activity was rated ninth. Similarly, respondents rated having a paid or unpaid job as part of one's school program as important, but they rated it low in frequency of student participation. Conversely, the student participation in career days and speakers from local businesses were rated high in frequency, but respondents perceived them to be low in importance for students. Pearson correlation indicated a strong relationship between the frequency and importance of speakers from local businesses. There was also a moderate relationship between the frequency and 
importance of school sponsored enterprise, tours of local businesses, and paid job outside of school program. As expected, there was no correlation between frequency and importance of apprenticeship. As discussed teachers perceived that participation in an apprenticeship is important for positive student post-school outcomes, yet these programs are not being offered to students in high school.

Table 8

Comparison of Mean Ratings of and Correlation Between Importance and Frequency of Specific Structured Work Experiences

\begin{tabular}{|c|c|c|c|c|}
\hline & $\begin{array}{c}\text { Importance } \\
\text { of structured } \\
\text { work } \\
\text { experience } \\
\end{array}$ & $\begin{array}{c}\text { Frequency of } \\
\text { structured } \\
\text { work } \\
\text { experience } \\
\end{array}$ & & \\
\hline $\begin{array}{c}\text { Structured work } \\
\text { experience }\end{array}$ & $M$ & $M$ & $\begin{array}{l}\text { Difference } \\
\text { between } M\end{array}$ & 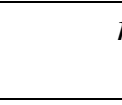 \\
\hline $\begin{array}{l}\text { Apprenticeship or } \\
\text { internship for specific } \\
\text { career }\end{array}$ & 5.24 & 2.49 & 2.75 & .01 \\
\hline $\begin{array}{l}\text { Career days or career } \\
\text { fairs }\end{array}$ & 4.59 & 4.11 & 0.48 & .22 \\
\hline $\begin{array}{l}\text { Job shadowing or job } \\
\text { sampling }\end{array}$ & 5.18 & 3.31 & 1.87 & .13 \\
\hline $\begin{array}{l}\text { Paid job outside of } \\
\text { school program }\end{array}$ & 4.67 & 3.05 & 1.62 & $.24 *$ \\
\hline $\begin{array}{l}\text { Paid or unpaid job as } \\
\text { part of school program }\end{array}$ & 5.00 & 2.79 & 2.21 & .19 \\
\hline $\begin{array}{l}\text { School-sponsored } \\
\text { enterprise or Youth-run } \\
\text { business }\end{array}$ & 3.89 & 1.92 & 1.97 & $.30^{*}$ \\
\hline $\begin{array}{l}\text { Service learning or } \\
\text { volunteer activities }\end{array}$ & 4.89 & 2.89 & 2.00 & .16 \\
\hline $\begin{array}{l}\text { Speakers from local } \\
\text { businesses }\end{array}$ & 4.08 & 3.21 & 0.87 & $.40^{* *}$ \\
\hline Summer jobs & 4.67 & 3.13 & 1.54 & .09 \\
\hline $\begin{array}{l}\text { Tours of local } \\
\text { businesses }\end{array}$ & 4.39 & 2.74 & 1.65 & $.29 *$ \\
\hline
\end{tabular}

Notes. ${ }^{*} p<.05 .{ }^{* *} p<.01$. 


\section{Quality of Implementation}

Respondents also rated the quality of implementation of each of the ten structured work experiences. The rating scale was one for "poor implementation" and six for “excellent implementation." Respondents also had the option to indicate that an activity was "not offered." For seven of the ten activities, at least $20 \%$ of respondents indicated that the activity was not offered at their school. The percentage of respondents who selected the "not offered" option was above 50\% in two instances (school-sponsored enterprises and apprenticeships) and ranged from 10.5\% (paid or unpaid job as part of school program) to $60.5 \%$ (school-sponsored enterprises).

Of those responses indicating that an activity was offered, the quality of implementation was not high for any activity. The highest mean rating was 3.7 (career days). School-sponsored enterprises, that activity least likely to be offered at respondents' schools, also had the lowest mean quality of implementation rating.

\section{Research Question 2: Barriers to Structured Work Experiences}

The second research question was "What are rural special education teachers' perceptions of the significance of barriers to implementation of structured work experiences?" Respondents rated the significance of a barrier, with one being "not a barrier" and six being "extreme barrier." Many barriers in the survey were seen to influence the implementation of structured work experiences occurring in respondents' schools. The most significant barriers related to student opportunities, included general employment opportunities and employment opportunities that match students' interests. The least significant barriers related to school personnel, included administrative support, teacher perceptions, and administration perceptions. Data on significance of barriers is 
Table 9

Ratings of the Quality of Implementation of Specific Structured Work Experiences

\begin{tabular}{|c|c|c|c|c|c|c|c|c|c|}
\hline $\begin{array}{l}\text { Structured work } \\
\text { experience }\end{array}$ & No Count & $1(\%)$ & $2(\%)$ & $3(\%)$ & $4(\%)$ & $5(\%)$ & $6(\%)$ & $M$ & $S D$ \\
\hline $\begin{array}{l}\text { Apprenticeship or } \\
\text { internship for specific } \\
\text { career }(n=18)\end{array}$ & $20(52.6)$ & $5(27.8)$ & $4(22.2)$ & $4(22.2)$ & $1(5.6)$ & $4(22.2)$ & $0(0.0)$ & 2.72 & 1.53 \\
\hline $\begin{array}{l}\text { Career days or career fairs } \\
(n=33)\end{array}$ & $5(13.2)$ & $2(6.1)$ & $4(12.1)$ & $8(24.2)$ & $8(24.2)$ & $9(27.3)$ & $2(6.1)$ & 3.73 & 1.33 \\
\hline $\begin{array}{l}\text { Job shadowing or job } \\
\text { sampling }(n=30)\end{array}$ & 7 (18.9) & $6(20.0)$ & $3(10.0)$ & $5(16.7)$ & $5(16.7)$ & $6(20.0)$ & $5(16.7)$ & 3.57 & 1.77 \\
\hline $\begin{array}{l}\text { Paid job outside of school } \\
\text { program }(n=29)\end{array}$ & $9(23.7)$ & $5(17.2)$ & $8(27.6)$ & $4(13.8)$ & $7(24.1)$ & $4(13.8)$ & $1(3.4)$ & 3.00 & 1.46 \\
\hline $\begin{array}{l}\text { Paid or unpaid job as part } \\
\text { of school program }(n=34)\end{array}$ & $4(10.5)$ & $6(17.6)$ & $5(14.7)$ & $7(20.6)$ & $8(23.5)$ & $6(17.6)$ & $2(5.9)$ & 3.26 & 1.52 \\
\hline $\begin{array}{l}\text { School-sponsored } \\
\text { enterprise or Youth-run } \\
\text { business }(n=15)\end{array}$ & $23(60.5)$ & $5(33.3)$ & $3(20.0)$ & $3(20.0)$ & $2(13.3)$ & $2(13.3)$ & $0(0.0)$ & 2.53 & 1.46 \\
\hline $\begin{array}{l}\text { Service learning or } \\
\text { volunteer activities ( } n= \\
\text { 29) }\end{array}$ & $9(23.7)$ & $4(13.8)$ & $10(34.5)$ & $5(17.2)$ & $4(13.8)$ & $4(13.8)$ & $2(6.9)$ & 3.00 & 1.51 \\
\hline $\begin{array}{l}\text { Speakers from local } \\
\text { businesses }(n=29)\end{array}$ & $9(23.7)$ & $7(24.1$ & $3(10.3)$ & $10(34.5)$ & $6(20.7)$ & $2(6.9)$ & $1(3.4)$ & 2.86 & 1.38 \\
\hline Summer jobs $(n=27)$ & $11(29.0)$ & $5(18.5)$ & $7(25.9)$ & $10(37.0)$ & $3(11.1)$ & $2(7.4)$ & $0(0.0)$ & 2.63 & 1.15 \\
\hline $\begin{array}{l}\text { Tours of local businesses } \\
(n=26)\end{array}$ & $11(29.7)$ & $9(34.6)$ & $3(11.5)$ & 7 (26.9) & $3(11.5)$ & $2(7.7)$ & $2(7.7)$ & 2.69 & 1.62 \\
\hline
\end{tabular}

Note. 1 = Poor implementation; 6 = Excellent implementation. Percentages for ratings from 1 to 6 , means, and standard deviations are calculated excluding "not offered" responses. 
Table 10

Ratings of the Significance of Each Barrier to the Implementation of Structured Work Experiences

\begin{tabular}{|c|c|c|c|c|c|c|c|c|}
\hline Barrier & $1(\%)$ & $2(\%)$ & $3(\%)$ & $4(\%)$ & $5(\%)$ & $6(\%)$ & $M$ & $S D$ \\
\hline $\begin{array}{l}\text { Accessibility of programs and curriculum }(n= \\
38)\end{array}$ & $2(5.3)$ & $3(7.9)$ & $11(29.0)$ & $6(15.8)$ & $9(23.7)$ & $7(18.4)$ & 4.00 & 1.45 \\
\hline Administration perceptions $(n=37)$ & $8(21.6)$ & $10(27.0)$ & $9(24.3)$ & $8(21.6)$ & $1(2.7)$ & $1(2.7)$ & 2.65 & 1.27 \\
\hline Administrator support $(n=38)$ & $13(34.2)$ & $10(26.3)$ & $7(18.4)$ & $6(15.8)$ & $1(2.6)$ & $1(2.6)$ & 2.34 & 1.32 \\
\hline Employer accommodations $(n=37)$ & $3(8.1)$ & $9(24.3)$ & $8(21.6)$ & $9(24.3)$ & $6(16.2)$ & $2(5.4)$ & 3.33 & 1.38 \\
\hline Employer perceptions $(n=38)$ & $5(13.2)$ & $9(23.7)$ & $7(18.4)$ & $11(29.0)$ & $3(7.9)$ & $3(7.9)$ & 3.18 & 1.45 \\
\hline Employment opportunities $(n=38)$ & $1(2.6)$ & $3(7.9)$ & $7(18.4)$ & $5(13.2)$ & $9(23.7)$ & $13(34.2)$ & 4.50 & 1.47 \\
\hline $\begin{array}{l}\text { Employment opportunities do not meet } \\
\text { student interests }(n=38)\end{array}$ & $1(2.6)$ & $1(2.6)$ & $6(15.8)$ & $11(29.0)$ & $9(23.7)$ & $10(26.3)$ & 4.47 & 1.27 \\
\hline Parent disengagement $(n=38)$ & $4(10.5)$ & $1(2.6)$ & $12(31.6)$ & $13(34.2)$ & $5(13.2)$ & $3(7.9)$ & 3.61 & 1.31 \\
\hline Preparation for high stakes testing $(n=38)$ & $2(5.3)$ & $4(10.5)$ & $6(15.8)$ & $13(34.2)$ & $6(15.8)$ & $7(18.4)$ & 4.00 & 1.41 \\
\hline Preparation time $(n=36)$ & $3(8.3)$ & $9(25.0)$ & $6(16.7)$ & $6(16.7)$ & $6(16.7)$ & $6(16.7)$ & 3.58 & 1.63 \\
\hline $\begin{array}{l}\text { Pressure to include students with disabilities } \\
\text { in general education curriculum }(n=38)\end{array}$ & $8(21.0)$ & $6(15.8)$ & $6(15.8)$ & $10(26.3)$ & $6(15.8)$ & $2(5.3)$ & 3.16 & 1.55 \\
\hline Resources (staff or funding) $(n=38)$ & $3(7.9)$ & $4(10.5)$ & $6(15.8)$ & $4(10.5)$ & $11(29.0)$ & $10(26.3)$ & 4.21 & 1.63 \\
\hline Scheduling $(n=37)$ & $1(2.7)$ & $3(8.1)$ & $9(24.3)$ & $7(18.9)$ & $6(16.2)$ & $11(29.7)$ & 4.27 & 1.47 \\
\hline School wide resources $(n=38)$ & $0(0.0)$ & $5(13.2)$ & $9(23.4)$ & $4(10.5)$ & $9(23.7)$ & $11(29.0)$ & 4.32 & 1.45 \\
\hline Severity of student disability $(n=38)$ & $5(13.2)$ & $10(26.3)$ & $5(13.2)$ & $11(29.0)$ & $6(15.8)$ & $1(2.6)$ & 3.16 & 1.41 \\
\hline Student challenging behavior $(n=38)$ & $5(13.2)$ & $5(13.2)$ & $7(18.4)$ & $10(26.3)$ & $9(23.7)$ & $2(5.3)$ & 3.50 & 1.47 \\
\hline Student disengagement $(n=38)$ & $2(5.4)$ & $4(10.8)$ & $10(27.0)$ & $11(29.7)$ & $6(16.2)$ & $4(10.8)$ & 3.73 & 1.33 \\
\hline Teacher perceptions $(n=38)$ & $9(23.7)$ & $10(26.3)$ & $9(23.7)$ & $8(21.0)$ & $1(2.6)$ & $1(2.6)$ & 2.61 & 1.28 \\
\hline $\begin{array}{l}\text { Teacher training in transition related skills ( } n \\
=38 \text { ) }\end{array}$ & $4(10.5)$ & $6(15.8)$ & $12(31.6)$ & $7(18.4)$ & $6(15.8)$ & $3(7.9)$ & 3.37 & 1.42 \\
\hline Transportation $(n=38)$ & $5(13.2)$ & $0(0.0)$ & $6(15.8)$ & $6(15.8)$ & $6(15.8)$ & $15(39.5)$ & 4.39 & 1.73 \\
\hline
\end{tabular}

Note. $1=$ Not a barrier; $6=$ Extreme barrier 
presented in Table 10.

Post-hoc, barriers were sorted into five categories: (a) attitudes, (b) lack of support from school districts, (c) changes made in recent legislation, (d) lack of community access, and (e) student and parent participation. Attitudes included: administrator perceptions, employer perceptions, and teacher perceptions. Lack of support from school districts included: accessibility of programs and curriculum, administrator support, preparation time, resources (staff or funding), scheduling, school wide resources, and teacher training in transition. Changes made in recent legislation included: preparation for high stakes testing and pressure to include students with disabilities in general education curriculum. Lack of community access included: employer accommodations, employment opportunities, employment opportunities do not meet students interests, and transportation. Student and parent participation included: parent disengagement, severity of student disability, student challenging behavior, and student disengagement. Mean group ratings were calculated for each category of barriers. The group of barriers with the lowest mean rating was attitudes $(\bar{x}=2.81)$, followed by student and parent participation $(\bar{x}=3.50)$, and changes made in recent legislation $(\bar{x}=$ 3.58). The groups of barriers with the highest mean ratings were community access $(\bar{x}=$ 4.05) and lack of support from school districts $(\bar{x}=3.73)$. 


\section{CHAPTER V \\ DISCUSSION}

In this chapter, I will present further discussion of my findings. First, I will discuss limitations to the study. Then I will discuss the relationship between my findings and existing literature. Finally, I will present considerations for future research and practice.

\section{Limitations}

The ability to be confident in or generalize from these findings is limited by the sample size. Only 51 responses to the survey were received; of these, only 39 were usable. Additionally, one of the respondents whose data was included in the results identified as a math teacher. Due to the format of the survey, I could not determine this individual's status as a special education professional: initial licensure, subsequent licensure, neither, or other. Because the initial letter of invitation and the informed consent document both clearly identified the purpose of the study and the target sample, I chose to assume the respondent had some licensure and/or responsibilities related to delivery of special education services and so included the survey response in my analysis.

The sample may also be biased. First, rural high school principals were asked to forward the email to high school special education teachers, transition specialists, and other related personnel. Principals who are supportive of special education and structured work experiences or find value in and are supportive of research may have been more likely to forward the email as requested and at the same time may lead schools with a 
culture that communicates the value of these activities. Second, the teachers and staff that were most likely to complete the survey are those that have an interest in and support structured work experience. With these limitations in mind, respondents in this study may have more awareness of, experience in, or appreciation for structured work experiences than the general population of rural secondary special education teachers in Illinois.

Additional limitations to the study involve the nature of survey research. While completing the survey, respondents may have been influenced by self-report bias, responding in the way they believe reflected a "correct" answer. A related limitation is that respondents may have incomplete or incorrect understanding of what each of the structured work experiences is or the extent to which each is offered at their schools.

\section{Discussion of Findings}

Despite these limitations, my findings offer a useful exploratory study of rural secondary school special education professionals related to structured work experiences and point to a number of issues that warrant further research. Below, I will present findings related to my initial research questions as well as discuss in more depth several particularly interesting specific findings, including: (a) the disconnect between experiences seen as beneficial by respondents and experiences being implemented in their schools, (b) the perceived significance of transportation as a barrier to implementation barrier, (c) the limited perceived significance of administrator support as a barrier, (d) the implied limited understanding of the longitudinal phases of career development, and (e) the limited perceived value of structured work experiences related to post-secondary education outcomes. 


\section{Research Question 1: Importance, Frequency of Participation, and Quality of Implementation of Structured Work Experiences}

My research investigated teachers' perceptions related to structured work experiences. The respondents to my survey reported that apprenticeship or internship was the most beneficial to students with disabilities. More than half of the respondents rated it to be extremely beneficial for student development and post-school outcomes. Other structured work experiences that were rated important by respondents included job shadowing and paid or unpaid job as part of school program. All of the structured work experiences were rated by respondents as more beneficial than not, with schoolsponsored enterprise being rated lowest.

The benefits that different types of structure work experiences have on the development of work related skills have been examined in prior research. Kim and Dymond (2010) explored teacher perceptions of the value of specific benefits of structured work experiences as a whole. In contrast, I examined perceptions of the level of benefit of specific structured work experiences. Combined, these two studies provide a broader understanding of the perceived benefit of structured work experiences but one that needs further examination.

A second aspect of my research was teacher perceptions of the frequency of student participation in structured work experience. Career days were the most common activity included in students' transition experiences. It was also the only activity respondents on average rated to have more the half of students with disabilities participating. Other structured work experiences that students participated in more frequently included: job shadowing, speakers from local businesses, summer jobs, and paid job outside of school program. Over $50 \%$ of the respondents rated school-sponsored 
enterprise as no participation by students with disabilities and it has the lowest overall student participation rating. More then $25 \%$ of the respondent also indicated that apprenticeship and tours of local businesses were not available to any student with disabilities.

Carter el al. (2010) explored the participation of students with disabilities (specifically students with severe disabilities or emotional and behavioral disorders) in career development activities. I included six of the same structured work experiences they used in their research. Of the six included in both surveys, tours and school sponsored enterprises were rated by the respondents differently. Carter et al. (2010) respondents rated tours and school sponsored enterprise as more frequently accessed by students with disabilities. Zhang, et al. (2005) also examined transition service and experiences received by students. There are four structured work experiences that we both examined; of these there was one noticeable difference in the data. Their findings suggested that students more frequently accessed paid or unpaid jobs as part of a school program.

My research also examined teacher perceptions of the quality of implementation of each structured work experience. A number of respondents replied that structured work experiences were not offered at their school. More than $50 \%$ of the respondents reported that school-sponsored enterprise and apprenticeship are not offered at their schools. Also, more that $20 \%$ of respondents replied that summer jobs, tours of local businesses, paid jobs outside of school program, service learning, speakers from local businesses, and tours of local businesses were not offer for students with disabilities at their schools. Of the structured work experiences that were offered, career days were 
rated to have the highest quality of implementation. Career days along with job shadowing were the only two structured work experiences whose implementation was rated overall to be better than average. All of the remaining structured work experiences were rated on average to be implemented poorly.

Zhang et al. (2005) reported respondents' ratings on the quality of school or district engaged students in transition activities. Only two structured work experiences were common across the surveys, and so a clean comparison between the two studies is hard to make. It appears that the respondents in Zhang et al. generally rated the quality of implementation higher than did my respondents. The difference should be confirmed or refuted by further research. If a difference is confirmed, this difference should be explored to explain why it is occurring and to examine if part of the difference relates to the rural nature of my respondents' schools.

\section{Research Question 2: Barriers to Structured Work Experiences}

The respondents perceived most barriers as significant. The most significant barrier was related to limited community access to structured work experiences. Rated the highest were employment opportunities, employment opportunities not meeting the students interests, and available transportation. Respondents rated most of the structured work experiences as barriers. The smallest barriers were administrator support, teacher perceptions, and administration perceptions. Out of the 38 respondents 13 replied that administrator support was not a barrier to implementation of structured work experiences.

Kim and Dymond (2010) identified special education teachers' perspectives on barriers to implementing community based vocational instruction. Seven similar barriers exist between the two studies. Ratings of the barriers were similar between the two 
surveys except for transportation and student challenging behaviors. My findings indicated that transportation was a greater barrier. The selected participants for Kim and Dymond's study were randomly selected from teachers in Illinois. Further research could be completed to see if this difference in perceived barriers is related to the location of the school districts. Kim and Dymond's respondents rated student challenging behavior as a greater barrier. Additional research could be completed to examine why this difference occurred. That difference may be attributed to the student population of the target sample.

\section{Benefits to Students}

The structured work experiences respondents saw as most beneficial to students with disabilities were not generally being implemented in their schools. The respondents reported that apprenticeship were the most beneficial to students with disabilities. They also reported that job shadowing and paid or unpaid jobs as part of a school program were beneficial. Of these three types of structured work experiences, apprenticeship and paid or unpaid job as part of a school program were both offered to fewer than half of the students. Five activities had no significant correlation between perceived importance and perceived frequency of participation: apprenticeship, summer jobs, paid or unpaid work as part of a school program, job shadows, and service learning. Most of these structured work experiences require personnel to plan and prepare for the activity. The other activities include career days, paid job outside of school program, school sponsored enterprise, speakers form local businesses, and tours of local businesses. Many of these activities do not require as much preparation by school personnel. Further research may 
be completed to see if the frequency in which a structured work experience is implemented is related to the time it takes personnel to plan and prepare.

The findings related to frequency of participation confirm previous research. Apprenticeships and paid work experiences are both identified practices in the Taxonomy of Transition Programming (Kohler, 1996), but Zhang et al. (2005) and Joshi et al. (2012) found that apprenticeships were among the least common structured work experiences available to students. Additional research should focus on why these recommended structured work experiences are not available to high school students. Examination of the extent to which these activities are offered to students without disabilities and how they are successfully implemented for those students may also yield insight to increase access for students with disabilities.

\section{Lack of Transportation}

Transportation continues to be identified as a barrier to successful implementation of structured work experiences in rural areas. Transportation was rated by respondents to be one of the most significant barriers to the implementation of structured work experiences. Transportation was also found to be a barrier by Collet-Klingenberg and Kolb (2011) and Carter et al. (2010). This lack of available transportation limits students' access to structured work experiences.

Collet-Klingenberg and Kolb (2011) and Morgan and Morgan (2006) recommend networking with communities and community members to secure transportation for students with disabilities. Further examination of these possibilities and the success of such programs should be completed. Stakeholders should also examine alternative programs or activities to provide students with opportunities that could be completed on 
the school's campus. Examples of these alternatives may include job shadowing a faculty member, career fairs on campus, school-sponsored enterprise or youth-run businesses, or speakers from local businesses. Of these, school-based enterprises may hold the most potential for providing an in depth and longitudinal experience that more closely addresses skill development in community-based structured work experiences, yet school-based enterprises were seen as having little value by respondents in this study.

\section{Significance of Administrator Support}

Surprisingly, respondents suggested that administrative support is not a significant barrier to implementation when they responded to it as a named barrier. This is in contrast to Kim and Dymond (2010); in that study, administrator support was rated as an important barrier to implementing structured work experiences. In this study, despite rating administrator support low, several other barriers that could be influenced directly by administrative support were seen as significant; preparation time, teacher training, and scheduling were among the highest rated barriers seen as influencing implementation and could be addressed through administrative support or action.

Further investigation should be conducted to determine teachers' perspectives on the influence that administrators have on each of these barriers related to support from school districts. Research can include the extent of influence teachers believe administrators have on each of these barriers. Additional research on administrators' perceptions of their role in and ability to increase implementation would also further our understanding of what aspects of a school community are influencing implementation. 


\section{Limited Connection to Middle School Experiences}

Career development for students with and without disabilities is a longitudinal process. Recommended practices suggest a K-12 approach to developing students' career goals and skills and promoting positive adult employment outcomes. In this study, respondents were asked to identify which of three grade levels — middle school, early high school, or late high school—were most appropriate for each of the ten specific structured work experiences. The data from this section of the survey reflected a lack of awareness or understanding of the longitudinal nature of career development.

Most career development models in the fields of special education and career and technical education identify at least three phases of development: awareness, exploration, and preparation. Brolin (1997) described four stages of career development: awareness, exploration, preparation, and assimilation. Of these stages his recommendation is that the first three happen while a student is in school, beginning with career awareness in elementary school (Brolin, 1997). Recommendations made by Morningstar (1997) were that career development begin during elementary and continue though high school and after a student graduates from high school. In general, recommended practices are to address awareness and exploration activities in elementary and middle school and preparation activities in high school. Of the ten activities included in this study, four are most commonly identified in the literature as awareness or exploration activities and hence may be most appropriate for elementary or middle school: career days or fairs, job shadows, speakers from businesses, and tours of businesses. Respondents in this study identified none of these four activities as appropriate most often for middle school students. Rather, all four were identified most often as appropriate for early high school. 
Further, job shadows were identified as most appropriate for late high school by $41 \%$ of respondents, despite the consensus among career development models that students should be in career preparation activities in high school. Only one activity, service learning or volunteer activities, was identified most frequently as most appropriate for middle school. Respondents may be unclear on the nature of these activities, the purpose of these activities, or the importance of middle school career development activities. These issues warrant further investigation.

\section{Influence of Structured Work Experiences on Post-School Education}

The teachers that I surveyed indicated that participation in structured work experiences had the least influence on attendance at a four-year college or university and community college. While recommended practices for school to work typically include recommendations related to post-secondary education paths, research on the effect of participating in structured work experiences on post-secondary education is limited. Further research is needed on the influence of participation in structured work experiences can have on enrollment and completion of post-secondary education programs for individuals with and without disabilities.

\section{Implications for Research and Practice}

Further research may be completed to better examine (a) the need for increase attention to apprenticeship and internships, (b) alternative structured work experiences that can be implemented at school, and (c) a larger population of rural teachers and/or complete with urban population to compare similarities and differences. First there is a need to determine the benefits of increasing the implementation of apprenticeships or internships. Researchers could complete a case study of current schools implementing 
apprenticeships or internships. They could focus on what and how to create a successful program. Teachers could be interviewed about the importance of apprenticeships or internships. From this study we know that respondent felt that these activities were beneficial to students with disabilities, but why do they perceive them as beneficial. Interviews of school personnel could also provide information on how these activities are being implemented for students without disabilities. If there is a difference in access for students, why is it different and what needs to be done to make these activities accessible for all students?

My study and all previous research indicate that transportation is a barrier to students with disabilities accessing structured work experiences; this is a greater concern in rural areas. In rural areas transportation is even more limited than for urban students. Most rural students do not have the opportunity to walk, ride a bike, ride a bus, take a cab, or any other type of pubic transportation to work. When implementing structured work experiences in rural schools, personnel may want to look at activities that can be completed and are beneficial for students that can be implemented at school. A survey or interview study of rural school district personnel should be completed to determine successful on campus structured work experiences are benefiting schools. Further, research on the effectiveness of campus-based structured work experiences should be conducted; to what extent can campus-based experiences meet the career development needs of students with disabilities?

I would like to see this survey completed by additional rural personnel. With a larger sample, a more accurate understanding of teachers and other personnel's perceptions may be developed. I also believe that it would be worthwhile to complete this 
survey with personnel working in urban schools. This would allow for comparisons and contrasts between urban and rural schools. The knowledge of these similarities could direct the need for further research in an area or areas within the survey that influence only rural or urban schools or it may identify aspects of structured work experiences that influence all schools. It could also lead to collaboration of ideas between these two types of schools.

Respondents to this survey agree that structured work experiences benefit rural high school students with disabilities. Respondents also agree that there are improvements that can be made to the implementation of these experiences. Rather than wait for the legislative pendulum to move back to placing value on career development, the field must examine what it is that impedes access for all students and then identify strategies to address those impediments. 


\section{REFERENCES}

Arnold, N. L., Seekins, T., \& Nelson, R. E. (1997). A comparision of vocational rehabilitiation counselors: Rural and urban differences. Rehabilitation Counseling Bulletin, 41(1), 2-14.

Baer, R. M., Daviso (III), A. W., Flexer, R. W., McMahan-Queen, R., \& Meindl, R. S. (2011). Students with intellectual disabilites: Predictors of transition outcomes. Career Develoment for Exceptional individuals, 34(3), 132-141. doi: $10.1177 / 0885728811399090$

Baer, R. M., Flexer, R. W., Beck, S., Amstutz, N., Hoffman, L., Brothers, J., \& Zechman, C. (2003). A collaborative follow-up study on transition service utilization and post-school outcomes. Career Development for Exceptional Individuals, 26(1), 7-25.

Benz, M. R., Lindstrom, L. L., Unruh, D. D., \& Waintrup, M. M. (2004). Sustaining secondary transition programs in local schools. Remedial and Special Education, 25(1), 39-50.

Benz, M. R., Lindstrom, L., \& Yovanoff, P. (2000). Improving graduation and employment outcomes of students with disabilities: Predictive factors and student perspectives. Exceptional Children, 66(4), 509-29.

Benz, M., Yovanoff, P., \& Doren, B. (1997). School-to-work components that predict post-school success for students with and without disabilities. Exceptional Children, 63(2), 155-165.

Brolin, D. E. (1997). Life centered career education: A competency based approach. (5th ed.). Reston, VA: Council for Exceptional Children.

Carter, E. W., Austin, D., \& Trainor, A. A. (2011). Factors associated with the early work experiences of adolescents with severe disabilities. Intellectual and Developmental Disabilities, 49, 233-247.

Carter, E. W., \& Hughes, C. (2006). Including high school students with severe disabilities in general education classes: Perspectives of general and special educators, paraprofessionals, and administrators. Research and Practice for Persons With Severe Disabilities (RPSD), 31(2), 174-185. 
Carter, E. W., Owens, L., Swedeen, B., Trainor, A. A., Thompson, C., Ditchman, N., \& Cole, O. (2009). Conversations that matter: Engaging communities to expand employment opportunities for youth with disabilities. TEACHING Exceptional Children, 41(6), 38-46.

Carter, E. W., Trainor, A. A., Cakiroglu, O., Cole, O., Swedeen, B., Ditchman, N., \& Owens, L. (2009). Exploring school-employer partnerships to expand career development and early work experiences for youth with disabilities. Career Development for Exceptional Individuals, 32(3), 145-159.

Carter, E. W., Trainor, A. A., Cakiroglu, O., Swedeen, B., \& Owens, L. A. (2010). Availability of and access to career development activities for transition-age youth with disabilities. Career Development for Exceptional Individuals, 33(1), 13-24.

Certo, N. J., \& Luecking, R. G. (2011). Transition and employment: Reflections from a 40 year perspective. Journal of Vocational Rehabilitation, 35(3), 157-161. doi. 10.3233/JVR-2011-0564

Chambers, D., Rabren, K., \& Dunn, C. (2009). A comparison of transition from high school to adult life of students with and without disabilities. Career Development for Exceptional Individuals, 32(1), 42-52.

Collet-Klingenberg, L. L., \& Kolb. S. M. (2011). Secondary transition programming fro 18-21 year old students in rural Wisconsin. Rural Special Education Quarterly, $30(2), 19-27$.

Doren, B., Gau, J. M., \& Lindstrom, L. E. (2012). The relationship between parent expectations and post-school outcomes of adolescents with disabilities.

Exceptional Children, 79(1), 7-23.

Dunn, C., Chambers, D., \& Rabren, K. (2004). Variables affecting students' decisions to drop out of school. Remedial and Special Education, 25(5), 314-323.

Dutton, M. (1995). An interview with J. D. Hoye, Director of the Federal National School-to-Work Office. NASSP Bulletin, 79(575), 17-20. doi:

$10.1177 / 019263659507957504$

Dymond, S. K., Renzaglia, A., \& Chun, E. J. (2008). Inclusive high school service learning programs: Methods for and barriers to including students with disabilities. Education and Training In Developmental Disabilities, 43(1), 20-36.

Dynarski, M., Clarke, L., Cobb, B., Finn, J., Rumberger, R., and Smink, J. (2008). Dropout prevention: A practice guide (NCEE 2008-4025). Washington, DC: National Center for Education Evaluation and Regional Assistance, Institute of 
Education Sciences, U.S. Department of Education. Retrieved from http://ies.ed.gov/ncee/wwc.

Estrada-Hernandez, N., Wadsworth, J. S., Nietupski, J. A., Warth, J., \& Winslow, A. (2008). Employment or economic success: The experience of individuals with disabilities in transition from school to work. Journal of Employment Counseling, $45(1), 14$.

Gemici, S., \& Rojewski, J. W. (2010). Contributions of cooperative education in preparing at-risk students for post-high school transition. Journal Of Education For Students Placed At Risk, 15(3), 241-258.

Guy, B. A., Sitlington, P. L., Larsen, M. D., \& Frank, A. R. (2009). What are high schools offering as preparation for employment? Career Development for Exceptional Individuals, 32(1), 30-41.

Hartman, M. A. (2009). Step by step: Creating a community-based transition program for students with intellectual disabilities. TEACHING Exceptional Children, 41(6), 611 .

Illinois State Board of Education. (2015). Data analysis and accountability. Rural/Urban Designations for Illinois School Districts (Locale Codes). Retrieved from www.isbe.net/research/htmls/directories.htm

Individuals With Disabilities Education Act, 20 U.S.C. §1401 et seq. (1990).

Individuals With Disabilities Education Act, 20 U.S.C. §1401 et seq. (1997).

Individuals With Disabilities Education Improvement Act, 20 U.S.C. §1401 et seq. (2004).

Joshi, G. S., Bouck, E. C., \& Maeda, Y., (2012). Exploring employment outcomes for students with mild intellectual disabilities. Career Development and Transition for Exceptional Individuals, 35(2), 97-107. doi: 10.1177/0885728811433822

Kim, R., \& Dymond, S. K. (2010). Special education teachers' perceptions of benefits, barriers, and components of community-based vocational instruction. Intellectual and Developmental Disabilities, 48(5), 313-329.

Kohler, P. D. (1993). Best practices in transition: Substantiated or implied?. Career Development for Exceptional Individuals, 16(2), 107-21.

Kohler, P. D. (1996). Taxonomy for transition programming. Champaign: University of Illinois. 
Landmark, L., Ju, S., \& Zhang, D. (2010). Substantiated best practices in transition: Fifteen plus years later. Career Development For Exceptional Individuals, 33(3), 165-176.

Larson, M. (2011). Practice brief: Engaging youth in work experiences. National Collaborative on Workforce and Disability for Youth, Washington, D.C. Retrieved from www.ncwd-youth.info/sites/default/files/PracticeBrief_2.pdf

Lemaire, G., Mallik, K., \& Stoll, B. G. (2002). High school/high tech: Promoting career exploration technology for youth with learning disabilities and behavioral disorders. Journal for Vocational Special Needs Education, 24(2-3), 30-39.

Li, J., Bassett, D. S., \& Hutchinson, S. R. (2009). Secondary special educators' transition involvement. Journal of Intellectual \& Developmental Disability, 34(2), 163-172.

Lindstrom, L., Doren, B., Flannery, B., \& Benz, M. (2012). Structured work experiences. In M. L. Wehmeyer \& K. Webb (Eds.) Handbook of adolescent transition education for youth with disabilities. New York: Routledge. (Invited peer reviewed chapter).

Lindstrom, L., Doren, B., Metheny, J., Johnson, P., \& Zane, C. (2007). Transition to employment: Role of the family in career development. Exceptional Children, 73(3), 348-366.

Lindstrom, L., Doren, B., \& Miesch, J. (2011). Waging a living: Career development and long-term employment outcomes for young adults with disabilities. Exceptional Children, 77(4), 423-43.

Lindstrom, L., Hirano, K. A., McCarthy, C., \& Alverson, C. Y. (2014). “Just having a living": Career advancement for low-wage workers with intellectual and developmental disabilities. Career Development and Transition for Exceptional Individuals, 37(1), 40-49. doi: 10.1177/2165143414522092

Lindstrom, L., Paskey, J., Dickinson, J., Doren, B., Zane, C., \& Johnson, P. (2007). Voices from the field: Recommended transition strategies for students and school staff. Journal For Vocational Special Needs Education, 29(2), 4-15.

Martin, E. J., Tobin, T. J., \& Sugai, G. M. (2002). Current information on dropout prevention: Ideas from the practitioners and the literature. Preventing School Failure, 47(1), 10-17.

Morgan, R. L., \& Morgan, R. B. (2006). Self-determined employment preferences for youth in transition from school to work in rural areas. Rural Special Education Quarterly, 25(4), 31-34. 
Morningstar, M. E. (1997). Critical issues in career development and employment preparation for adolescents with disabilities. Remedial and Special Education, 18(5), 307-20.

National Transition Network. (1994). Policy update: Youth with disabilities and the School-to-Work Opportunities Act of 1994. Minneapolis, MN: Author.

Newman, L., Wagner, M., Knokey, A., Marder, C., Nagle, K., Shaver, D., Wei, X., with Cameto, R., Contreras, E., Ferguson, K., Greene, S., \& Schwarting, M. (2011). The post-high school outcomes of young adults with disabilities up to 8 years after high school: A report from the national longitudinal transition study-2 (NLTS2). (NCSER 2011-3005). Menlo Park CA: SRI International.

Nietupski, J., Warth, J., Winslow, A., Johnson, R., Douglas, B., Johnson, M., \& Cilek, J. (2006). Iowa's high school super senior school-to-work transition program. Journal for Vocational Special Needs Education, 29(1), 17-29.

Perry, J. C., \& Wallace, E. W. (2012). What schools are doing around career development: Implications for policy and practice. New Directions for Youth Development, (134), 33-44.

Rabren, K., Dunn, C., \& Chambers, D. (2002). Predictors of post-high school employment among young adults with disabilities. Career Development for Exceptional Individuals, 25(1), 25-40.

Repetto, J. B., McGorray, S. P., Wang, H., Podmostko, M., Andrews, W. D., Lubbers, J., \& Gritz, S. (2011). The high school experience: What students with and without disabilities report as they leave school. Career Development for Exceptional Individuals, 34(3), 142-152.

Rowe, D. A., Alverson, C. Y., Unruh, D. K., Fowler, C. H., Kellems, R., \& Test, D. W. (2014). A Delphi study to operationalize evidence based predictors in secondary transition. Career Development and Transition for Exceptional Individuals, March 26, 1-14. doi: 10.1177/2165143414526429

Sabbatino, E. D., \& Macrine, S. L. (2007). Start on success: A model transition program for high school students with disabilities. Preventing School Failure, 52(1), 3339.

Scholl, L., \& Mooney, M. (2004). Youth with disabilities in work-based learning programs: Factors that influence success. Journal for Vocational Special Needs Education, 26(1-2), 4-16.

School-to-Work Opportunities Act, Public Law 103-239, 108 Stat 568, May 4, 1994, (20 U.S.C.6 101-6235). Retrieved from http://www2.ed.gov/pubs/Biennial/9596/eval/410-97.pdf 
Simonsen, M. L., \& Neubert, D. A. (2012). Transitioning youth with intellectual and other disabilities: Predicting community employment outcomes. Career Development and Transition for Exceptional Individuals, 36(3), 188-198. doi: $10.1177 / 2165143412469399$

Smink, J., \& Reimer, M. (2009). Rural school dropout issues: Implications for dropout prevention strategies and programs. National Dropout Prevention Center/Network. Clemson University. Clemson, SC. Retrieved from www.dropoutprevention.org

Stasz, C., \& Brewer, D. J. (1998). Work-based learning: Student perspectives on quality and links to school. Educational Evaluation And Policy Analysis, 20(1), 31-46.

Stasz, C., \& Stern, D. (1998). Work-based learning for students in high schools and community colleges. National Center for Research in Vocational Education, University of California, Berkeley, CA. Number 1 December 1998.

Test, D. W., Aspel, N. P., \& Everson, J. M. (2006). Transition methods for youth with disabilities. Upper Saddle River, NJ: Person Education, Inc.

Test, D. W., Fowler, C. H., Richter, S. M., White, J., Mazzotti, V., Walker, A. R., \& Kortering, L. (2009). Evidence-based practices in secondary transition. Career Development for Exceptional Individuals, 32(2), 115-128.

Test, D. W., Mazzotti, V. L., Mustian, A. L., Fowler, C. H., Kortering, L., \& Kohler, P. (2009). Evidence-based secondary transition predictors for improving post-school outcomes for students with disabilities. Career Development for Exceptional Individuals, 32(3), 160-181. doi: 10.1177/0885728809346960

Tilson, G. P, Luecking, R. G., and Donovan, M. R. (1994). Involving employers in transition: The bridges model. Career Development for Exceptional Individuals, 17(1), 77-89. DOI:10.1177/088572889401700107

Timmons, J. C., Hall, A. C., Bose, J., Wolfe, A., \& Winsor, J. (2011). Choosing employment: Factors that impact employment decisions for individuals with intellectual disability. Intellectual and Developmental Disabilities, 49, 285-299.

Trainor, A. A., Carter, E. W., Owens, L. A., \& Swedeen, B. (2008). Special educators' perceptions of summer employment and community participation opportunities for youth with disabilities. Career Development for Exceptional Individuals, 31(3), 144-153.

U.S. Bureau of Labor Statistics. (2014). Economic news release: Persons with a disability: Labor force characteristics summary. Washington, DC: Bureau of Labor Statistics. Retrieved from: http://www.bls.gov/news.release/disabl.nr0.htm 
U.S. Census Bureau, Geography. (2015). Urban and rural classification. Retrieved from www.census.gov/geo/reference/urban-rural.html

U.S. Department of Agriculture, (2014). Employment and education, economic research service. Retrieved from www.ers.usda.gov/topics/rural-economy-population/ employment-education.aspx

U.S. Department of Agriculture. (2014). Rural America at a glance, economic research service. Economic Brief Number 26. Retrieved from www.ers.usda.gov/media/ 1697681/eb26.pdf

U.S. Department of Education, National School to Work Office. (1999). School to work glossary of terms. Retrieved from http://files.eric.ed.gov/fulltext/ ED411444.pdf

U.S. Department of Education, National Center for Education Statistics. (2006). Common core of data, identification of rural locales. Retrieved from nces.ed.gov/ccd/ rural_locales.asp

U.S. Department of Labor. (2014). Persons with a disability: Labor force characteristics summary 2013. Bureau of Labor Statistics, Washington, D.C. Retrieved from http://www.bls.gov/news.release/disabl.nr0.htm

Wandry, D., Webb, K., Williams, J., Bassett, D., Asselin, S., \& Hutchinson, S. (2008). Teacher candidates' perceptions of barriers to effective transition programming. Career Development for Exceptional Individuals, 31(1), 14-25. Retrieved from Education Research Complete database.

Wehman, P. (2013). Transitions for school to work: Where are we and where do we need to go? Career Development and Transition for Exceptional Individuals, 36(1), 5866. doi: $10.1177 / 2165143413482137$

White, J., \& Weiner, J. S. (2004). Influences of least restrictive environment and community based training on integrated employment outcomes for transitioning students with sever disabilities. Journal of Vocational Rehabilitation, 21, 149156.

Zhang, D., Ivester, J. G., Chen, L. J., \& Katsiyannis, A. (2005). Perspectives on transition practices. Career Development for Exceptional Individuals, 28(1), 15-25. doi: $10.1177 / 08857288050280010401$ 
APPENDIX A

SURVEY INSTRUMENT 


\section{Survey on Structured Work Experiences for Students with Disabilities in Rural Schools}

1. Examination of rural special education teachers' perspectives on structured work experiences for youth with disabilities

You are asked to participate in a research study by Abby Lies, a Master's degree student in the Department of Special Education at Illinois State University, and her faculty mentor, Dr. Debbie Shelden. You have been asked to participate in this study because you are a special education teacher, vocational or work coordinator, or transition specialist in a rural secondary school in the state of Illinois. Your participation in this study is entirely voluntary. You should read the information below carefully before deciding whether or not to participate. Should you have any questions regarding this information or about the survey itself, you should contact Abby Lies or Dr. Debbie Shelden using the contact information below. The survey should take approximately 2030 minutes to complete.

\section{Purpose of Study}

Structured work experiences have been identified as a transition practice. Limited research on current availability and perceptions of structured work experiences is available. No research focusing specifically on availability and perceptions of structured work experiences in rural school districts has been reported. The purpose of this study is to examine the perceptions of high school special education teachers, vocational or work coordinators, and transition specialists in rural school districts related to structured work experiences. 


\section{Procedures}

If you volunteer to participate in this study, we ask you to complete an online survey. This should take about 15-30 minutes.

\section{Privacy and Confidentiality}

You are being asked to complete an anonymous, online survey. No identifying information about you, the location where you complete the survey, your school, your district, or your specific responses to the questions is collected from your computer nor can it be retained by the online survey system. No identifiable information about you or provided by you during this research can or will be disclosed to others by the researchers.

\section{Participation and Withdrawal}

Your participation in this research is entirely VOLUNTARY. If you choose not to participate, that will not affect your relationship with your current supervisors or employers who will not be informed by the researchers whether you participated in the study. If you decide to participate, you are free to withdraw your consent and discontinue participation at any time before or during your completion of the survey. You may skip any questions you do not wish to answer.

\section{Potential Risks to You}

There are some small risks to participating in the survey. There may be a slight risk to your anonymity. Your school district may have software that closely monitors the computer use and activity of students and staff. Because the responses to this survey involve information about the structured work experiences at your school, you may wish to complete this survey on a non-school computer at a location other than school if you feel that there is any risk to your anonymity or employment by completing this survey at 
school or on a school computer.

\section{Potential Benefit to You}

Although there may be no direct benefit to you, the possible benefit of your participation may assist teacher educators, practicing teachers and school administration, and researchers in more effectively preparing for and implementing structured work experiences. This study may add to the existing knowledge base on structured work experiences in rural high schools.

If you have any questions concerning the research study, please contact Abby Lies at 217.840 .4438 or by email at amlies@ilstu.edu or Dr. Debbie Shelden at 309.438.5661 or by email at dlsheld@ilstu.edu. If you have any questions about your rights as a participant in this research, or if you feel you have been placed at risk, you can contact the Research Ethics \& Compliance Office at Illinois State University at 309.438.2529 and/or rec@ilstu.edu

Sincerely, Abby Lies

\section{Confirmation of Research Subject}

By clicking I give consent to participate in this research.

Yes. I give my consent to participate.

No. I do not want to participate. 


\section{Structured Work Experience Definitions}

Structured work experience refers to any community based volunteer, assessment, exploration, or training work or opportunity that helps students develop work goals, build employability skills, connect to work, and increase career opportunities and options. Types of Structured Work Experiences

\begin{tabular}{|c|c|}
\hline Models & Definition \\
\hline $\begin{array}{l}\text { Apprenticeship } \\
\text { or internship for } \\
\text { specific career }\end{array}$ & $\begin{array}{l}\text { Students work for an employer, paid or unpaid, to learn about and } \\
\text { industry or occupation. (Lindstrom et al., 2012; School to work } \\
\text { glossary of terms, National School to Work Office, 1999). } \\
\text { Students learn an occupation while under the supervision of an } \\
\text { experienced worker (Test et al., 2006). Youth apprenticeship } \\
\text { combine school and work-based learning to teach students a } \\
\text { specific occupation or cluster. Youth apprenticeships lead to post- } \\
\text { secondary programs, entry-level jobs, or registered apprenticeship } \\
\text { programs (National School to Work Office, 1999). }\end{array}$ \\
\hline
\end{tabular}

Career days or career fairs

Job shadowing or job sampling

Paid job outside of school program

Paid or unpaid job as part of school program
Students learn about their career interest and abilities by meeting with post-secondary educators, employers, employees, or human resource professional (National School to Work Office, 1999).

Students explore a range of career objectives by spending a few hours observing at worksites alongside employees to develop an understanding of the job duties (National School to Work Office, 1999; Stasz \& Stern, 1998; Test et al., 2006).

Students engage in off-campus standard paid job, often after school or on weekends. (Lindstrom et al., 2012; Stasz \& Stern, 1998).

Students engage in paid or unpaid work experiences in while supervised by school personnel. The students learn general work place skills (Lindstrom, 2014). These employment opportunities can provide students with a number of workplace experiences (Lindstrom, 2014).

School sponsored enterprise or Youth-run business Table continues
Students manage and work with other classes or school activities to produce goods or provide services for others within the school setting (Lindstrom et al., 2012; National School to Work Office, 1999; Stasz \& Stern, 1998). Students create, produce, and sell various products they have created (Larson, 2011). 
Service learning Students usually work in a government office or nonprofit agency or volunteer focus is on serving the community rather than building students' activities skills (Stasz \& Stern, 1998). Students gain skills and knowledge, while providing the community with a service, by combining community service with opportunities for reflection (National School to Work Office, 1999). Students are provided the opportunity for practice employability skills (Test et al., 2006).

Speakers from Students attend professional speakers in their classroom to gather local businesses information about job expectations (Carter et al., 2010).

Summer jobs On-the-job work experience with various job sites through local business and organizations during the summer (Larson, 2011).

Tours of local Students visit potential employers to gather information about job businesses expectations (Carter et al., 2010).

\section{Section 1: Teacher Characteristics}

2. Gender:

Male

Female

3. Years of teaching experience:

$0-5$

$6-10$

$11-15$

$16-20$

$21+$ 
4. Primary job classification?

Special Education Teacher

Vocational or Work Coordinator

Transition Specialists

Other, please specify

5. Highest degree earned?

_ Bachelors

Masters

Doctorate

Other, please specify

6. Bachelor's degree field?

Special Education

_ Vocational Education

__ Business Education

Other, please specify

7. What grade level(s) do you currently teach? (check all that apply) 9

10

11

12 
8. What are the categories of disability of the students you work with? (check all that apply)

Specific learning disabilities

Emotional and behavioral disorders

Intellectual disabilities

Autism

Multiple disabilities

Other health impairments

Students without disabilities

9. What is the primary category of disability of students you work with? (check one) Specific learning disabilities Emotional and behavioral disorders

Intellectual disabilities

Autism

Multiple disabilities

Other health impairments

Students without disabilities 
10. How much time do you devote to transition related responsibilities each week? $<2$ hours

2-5 hours

6-10 hours

$10+$ hours

\section{Section II: School Characteristics}

11. Is your high school located within a town/city limits or outside of a town/city? Yes, my school is inside of town/city limits No, my school is outside of town/city limits

12. If your school is in town/city limits, what is the approximate population of the town?

13. If your school is outside of town/city limits, approximately how far is the nearest town?

14. If your school is outside of town/city limits, what is the nearest town's population? 
15. Approximate number of student enrolled in your school?

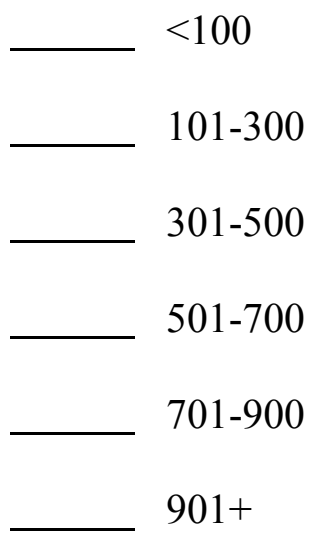

16. Approximate number of students receiving special education services in your school?

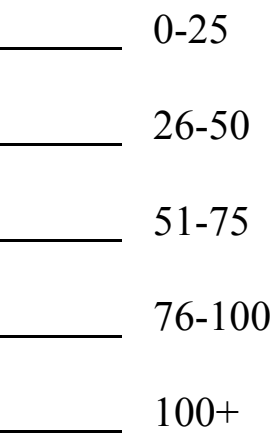

17. Does your high school have a Career and Technical Education (CTE) program?

Yes
No
I don't know

18. Does your high school offer Secondary Transitional Experience (STEP) services?

Yes

- No 
19. Is community service a graduation requirement?

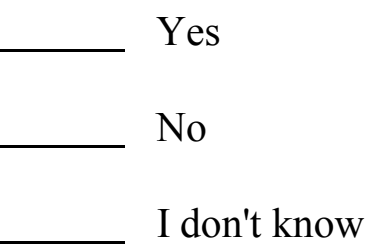

\section{Section III: Specific Structured Work Experiences}

In this section, you will rate your perception of the importance, frequency, and impact of specific structured work experiences. If you are unsure of what a specific work experience activity is, you can refer back to the definitions.

20. Importance of Structured Work Experiences

For each activity, indicate how beneficial participation in the activity is for student development and post school outcomes for students with disabilities. $(1=$ not beneficial to $6=$ extremely beneficial)

\begin{tabular}{lcccccc}
\hline & $\begin{array}{c}1 \\
\text { Not }\end{array}$ & 2 & 3 & 4 & 5 & $\begin{array}{c}6 \\
\text { Extremely } \\
\text { beneficial }\end{array}$ \\
$\begin{array}{lccccc}\text { Apprenticeship } \\
\text { or internship } \\
\text { for specific } \\
\text { career }\end{array}$ & 0 & 0 & 0 & 0 & 0 & 0 \\
$\begin{array}{l}\text { Career days or } \\
\text { career fairs }\end{array}$ & 0 & 0 & 0 & 0 & 0 & \\
\end{tabular}




\begin{tabular}{|c|c|c|c|c|c|c|}
\hline $\begin{array}{l}\text { Job shadowing } \\
\text { or job sampling }\end{array}$ & ○ & ○ & ○ & ○ & ○ & $\circ$ \\
\hline $\begin{array}{l}\text { Paid job outside } \\
\text { of school } \\
\text { program }\end{array}$ & ○ & ○ & O & ० & ० & ○ \\
\hline $\begin{array}{l}\text { Paid or unpaid } \\
\text { job as part of } \\
\text { school program }\end{array}$ & O & ○ & ○ & ○ & ○ & ○ \\
\hline $\begin{array}{l}\text { School } \\
\text { sponsored } \\
\text { enterprise or } \\
\text { Youth-run } \\
\text { business }\end{array}$ & ○ & ० & O & ० & ० & ○ \\
\hline $\begin{array}{l}\text { Service } \\
\text { learning or } \\
\text { volunteer } \\
\text { activities }\end{array}$ & ० & ० & ० & ○ & ○ & ○ \\
\hline $\begin{array}{l}\text { Speakers from } \\
\text { local businesses }\end{array}$ & O & ○ & O & ○ & O & ○ \\
\hline Summer jobs & o & o & o & o & o & ○ \\
\hline $\begin{array}{l}\text { Tours of local } \\
\text { businesses }\end{array}$ & ○ & ○ & ○ & ○ & o & ○ \\
\hline
\end{tabular}

21. Additional comments on the importance of structured work experiences for improving adult or post-school outcomes for students with disabilities. 


\section{Section III: Specific Structured Work Experiences}

In this section, you will rate your perception of the importance, frequency, and impact of specific structured work experiences. If you are unsure of what a specific work experience activity is, you can refer back to the definitions.

\section{Implementation of Structured Work Experiences}

For each activity, indicate how well you think the activity is implemented for students with disabilities at your school. (Not offered; $1=$ poor implementation to $6=$ excellent implementation)

\begin{tabular}{|c|c|c|c|c|c|c|c|}
\hline & $\begin{array}{c}\text { Not } \\
\text { offered }\end{array}$ & $\begin{array}{c}1 \\
\text { Poor } \\
\text { implementation }\end{array}$ & 2 & 3 & 4 & 5 & $\begin{array}{c}6 \\
\text { Excellent } \\
\text { implementation }\end{array}$ \\
\hline $\begin{array}{l}\text { Apprenticeship } \\
\text { or internship } \\
\text { for specific } \\
\text { career }\end{array}$ & 0 & 0 & 0 & 0 & 0 & 0 & 0 \\
\hline $\begin{array}{l}\text { Career days or } \\
\text { career fairs }\end{array}$ & o & 0 & 0 & 0 & o & o & o \\
\hline $\begin{array}{l}\text { Job shadowing } \\
\text { or job } \\
\text { sampling }\end{array}$ & o & o & o & 0 & o & o & o \\
\hline $\begin{array}{l}\text { Paid job } \\
\text { outside of } \\
\text { school } \\
\text { program }\end{array}$ & O & O & O & 0 & o & o & o \\
\hline $\begin{array}{l}\text { Paid or unpaid } \\
\text { job as part of } \\
\text { school } \\
\text { program }\end{array}$ & O & O & 0 & o & O & 0 & o \\
\hline
\end{tabular}


School

sponsored

enterprise or

Youth-run

business

Service

learning or

volunteer

activities
○

O
○

0

o

○

○

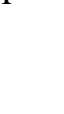

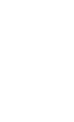


26. Implementation of Structured Work Experiences

Which grade level is the most appropriate for students with disabilities to participate in each specific structured work experience?

\begin{tabular}{|c|c|c|c|}
\hline & Middle school & Early high school & Late high school \\
\hline $\begin{array}{l}\text { Apprenticeship or } \\
\text { internship for specific } \\
\text { career }\end{array}$ & o & 0 & 0 \\
\hline $\begin{array}{l}\text { Career days or career } \\
\text { fairs }\end{array}$ & o & $\circ$ & o \\
\hline $\begin{array}{l}\text { Job shadowing or job } \\
\text { sampling }\end{array}$ & o & o & o \\
\hline $\begin{array}{l}\text { Paid job outside of } \\
\text { school program }\end{array}$ & 0 & o & $\circ$ \\
\hline $\begin{array}{l}\text { Paid or unpaid job as } \\
\text { part of school program }\end{array}$ & o & o & o \\
\hline $\begin{array}{l}\text { School sponsored } \\
\text { enterprise or } \\
\text { Youth-run business }\end{array}$ & O & O & O \\
\hline $\begin{array}{l}\text { Service learning or } \\
\text { volunteer activities }\end{array}$ & $\circ$ & $\circ$ & $\circ$ \\
\hline $\begin{array}{l}\text { Speakers from local } \\
\text { businesses }\end{array}$ & 0 & o & 0 \\
\hline Summer jobs & o & O & O \\
\hline $\begin{array}{l}\text { Tours of local } \\
\text { businesses }\end{array}$ & ० & o & ० \\
\hline
\end{tabular}

27. Additional comments on grade levels for the implementation of structured work experiences for students with disabilities by your school. 


\section{Section IV: Barriers to Structured Work Experiences}

28. Barriers to Structured Work Experiences

How significant is each of the following barriers to the implementation of structured work experiences for students with disabilities occurring at your school? $(1=$ not a barrier to $6=$ extreme barrier)

\begin{tabular}{|c|c|c|c|c|c|c|}
\hline & $\begin{array}{c}1 \\
\text { Not a } \\
\text { barrier }\end{array}$ & 2 & 3 & 4 & 5 & $\begin{array}{c}6 \\
\text { Extreme } \\
\text { barrier }\end{array}$ \\
\hline Employer perceptions & o & o & o & o & O & o \\
\hline Teacher perceptions & O & O & O & ○ & ○ & o \\
\hline $\begin{array}{l}\text { Administration } \\
\text { perceptions }\end{array}$ & O & $\circ$ & O & $\circ$ & ० & ○ \\
\hline Parent disengagement & ○ & $\circ$ & O & ○ & ० & ○ \\
\hline Student disengagement & 0 & O & O & $\circ$ & ० & o \\
\hline Administrator support & O & ○ & O & ○ & O & O \\
\hline $\begin{array}{l}\text { Resources (staff or } \\
\text { funding) }\end{array}$ & ○ & $\circ$ & O & $\circ$ & ० & ○ \\
\hline Preparation time & ○ & $\circ$ & ० & ○ & ० & ○ \\
\hline $\begin{array}{l}\text { Teacher training in } \\
\text { transition related skills }\end{array}$ & o & O & 0 & ० & ० & o \\
\hline Transportation & ○ & $\circ$ & ० & O & ० & ○ \\
\hline Scheduling & o & O & ○ & O & ○ & o \\
\hline $\begin{array}{l}\text { Accessibility of programs } \\
\text { and curriculum }\end{array}$ & o & ० & O & O & ○ & o \\
\hline School wide resources & O & $\circ$ & O & O & O & ० \\
\hline $\begin{array}{l}\text { Pressure to include } \\
\text { students with disabilities } \\
\text { in general education } \\
\text { curriculum }\end{array}$ & ○ & $\circ$ & $\circ$ & $\circ$ & ○ & ० \\
\hline $\begin{array}{l}\text { Preparation for high } \\
\text { stakes testing }\end{array}$ & O & $\circ$ & ० & ० & ० & ० \\
\hline
\end{tabular}




\begin{tabular}{|c|c|c|c|c|c|c|}
\hline $\begin{array}{l}\text { Employment } \\
\text { opportunities }\end{array}$ & 0 & 0 & 0 & 0 & o & 0 \\
\hline $\begin{array}{l}\text { Employment } \\
\text { opportunities do not meet } \\
\text { student interests }\end{array}$ & 0 & 0 & o & 0 & o & 0 \\
\hline $\begin{array}{l}\text { Employer } \\
\text { accommodations }\end{array}$ & 0 & 0 & O & 0 & 0 & 0 \\
\hline $\begin{array}{l}\text { Student challenging } \\
\text { behavior }\end{array}$ & 0 & 0 & 0 & 0 & 0 & 0 \\
\hline $\begin{array}{l}\text { Severity of student } \\
\text { disability }\end{array}$ & 0 & O & 0 & 0 & 0 & 0 \\
\hline
\end{tabular}

29. Additional comments on barriers that affect implementation of structured work experiences for students with disabilities.

\section{Section V: Impact of Structured Work Experiences}

Intro to section: Now that you have responded to items about specific structured work experiences, we want you to think about structured work experiences in general (consider all possible structured work experience activities).

\section{Impact of Structured Work Experiences}

How much does participation in structured work experiences influence the following outcomes for students with disabilities: $(1=$ no influence to $6=$ extreme influence $)$ 


\begin{tabular}{|c|c|c|c|c|c|c|}
\hline & $\begin{array}{c}1 \text { No } \\
\text { influence }\end{array}$ & 2 & 3 & 4 & 5 & $\begin{array}{c}6 \\
\text { Extreme } \\
\text { influence }\end{array}$ \\
\hline $\begin{array}{l}\text { High school } \\
\text { completion }\end{array}$ & 0 & 0 & 0 & O & 0 & o \\
\hline $\begin{array}{l}\text { Attendance at a four- } \\
\text { year college university }\end{array}$ & o & ○ & ○ & O & 0 & 0 \\
\hline $\begin{array}{l}\text { Attendance at } \\
\text { community college }\end{array}$ & ○ & ○ & ○ & ○ & O & ○ \\
\hline $\begin{array}{l}\text { Employment post } \\
\text { high school }\end{array}$ & o & ○ & ○ & ○ & ○ & o \\
\hline Independent living & o & o & o & o & 0 & o \\
\hline
\end{tabular}

31. How many students with disabilities from your school participate in any form of structured work experiences?

$\begin{array}{ll}{\left[\begin{array}{l}{[} \\ {[}\end{array}\right.} & 10-20 \\ & 21-30 \\ & 30+ \\ & \text { I don't know }\end{array}$

32. Additional comments on the effect of structured work experiences on the post-school outcomes for individuals with disabilities. 


\section{Section VI: Teacher Preparation}

33. Do you have any experience developing and implementing structured work experiences with students with disabilities?

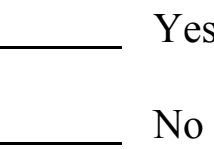

34. How prepared do you feel you are to provide structured work experiences for students with disabilities?

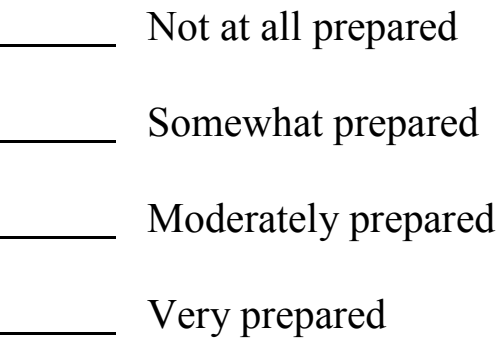

35. How prepared do you feel to incorporate a student's structured work experiences into academic content?

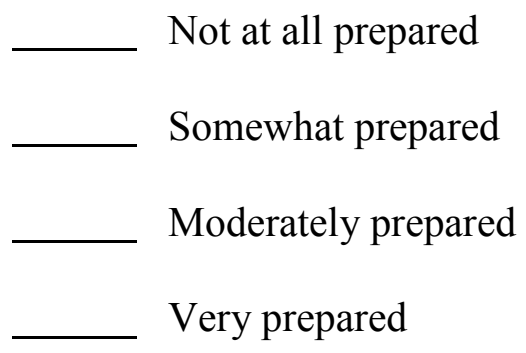

36. Describe any professional development or education related to structured work experiences you have had. 